\title{
İslam Hukukunda Telfîk Nazariyyesi
}

\section{Emrah DEMIRTAŞ*}

Arş. Gör. İbrahim SizGEN**

Atıf / @-- Demirtaş, E. - Sizgen, İ. (2018). İslam Hukukunda Telfîk Nazariyyesi, Çukurova Üniversitesi Illahiyat Fakültesi Dergisi, 18 (1), 535-567.

Öz- İslâm Hukuku canlı, dinamik ve yürürlükte olan bir hukuktur. Bu dinamikliğini Islam hukuku, fukahânın nassa dayalı içtihatlarından almıştır. Nitekim Mecelle maddelerinde yer alan ve ulema tarafından önem atfedilen "Zamanın değişimiyle, hükümlerin değişmesi inkâr edilemez" kaidesi bunu açıkça ifade etmektedir. Şer'î-amelî hükümlerden olup yaşadığımız çağda bir problem haline gelen telfik ve telfik ile ilgili olan taklid, mezhepler arası intikal, tetebu'rruhas, teysir ve ihdasu Kavli's-sâlis (üçüncü görüş ortaya çıkarma) gibi lafızlar temelde her ne kadar birbiriyle aynı oldukları gözlemlense de amelî boyutta bu kavramlar birbirine zıt oldukları anlaşılmıştır. Terim olarak farklı görüş ve hükümleri birleştirmek anlamına gelen telfîk, hicri yedinci asırdan itibaren usûlcüler arasında tartışılan bir konu olmuştur. İslâm Hukukunda içtihada dayalı bir mesele olan telfîk, genellikle fıkıh usûlü kaynaklarının taklit bölümünde ele alınmış olup birçok risalede işlenmiştir. Dolayısıyla telfîk, içtihatta ve taklitte olmak üzere ikiye ayrılır. İsmail Hakkı İmirli, telfiki tek bir olayda ve iki olayda gerçekleşen olmak üzere iki bölümde ele almıştır. Seyyid Bey ise icmâya muhâlif olan ve olmayan şeklinde taksimde bulunmuştur. Müçtehitler döneminden sonra uygulamada telfîke başvurulmuş, ayrıca her mezhep müçtehitlerinin görüşleri arasında telfîk dinin hükümlerini hafife almamak kaydıyla genellikle câiz görülmüştür. Telfîkin câiz olmadığını ileri süren fakihler de vardır. Ancak onların bu tutumu aşırılık ve bağnazlık gibi ifadelerle eleştirilmiş ve nassın ruhuna aykırı olmayacak şekilde iyi niyet besleyen müleffikin (telfik yapan kişi) telfiki usûlcülerce kabul görmüştür.

Anahtar sözcükler- Telfîk, taklid, içtihad, İslam hukuku, teysir

Makalenin gelişi: 23.01.2018; Yayına kabul tarihi: 12.06.2018

* Kayseri Dinî Yüksek İhtisas Merkezi Müd. Kursiyeri, e-posta: emrahdemirtas@hotmail.com (ORCID: 000000033967 4523)

** Mustafa Kemal Üniversitesi İlahiyat Fakültesi İslam Hukuku Anabilim Dalı, e-posta: ibrahimsizgen@hotmail.com (ORCID: 000000033669 8589) 


\section{$\S \S \S$}

\section{ISLAM HUKUKUNDA TELFÎK}

\subsection{Telfik'in Sözlük Anlamı}

Köken olarak لفق mazi filinin sülâsî mudaaf filinin mastarı olan telfîk, iki kumaşı bir araya getirmek, iki şeyi birleştirmek, kumaşın iki tarafını yan yana getirip dikmek için birleştirmek ve iki dudağı birleştirerek konuşmaya çalışmak manalarında kullanılmıştır. "Herhangi bir kavim telfîk etti" denildiğinde ise mecâzî olarak aralarının düzeldiği manası kastedilmiş̧ir. ${ }^{1}$ Ayrıca telfîk kelimesi uydurmak, süslemek, ulaşmak, iltihak etmek, anlamak, elde etmek ve eli boş dönmek anlamlarında da kullanılmıştır.2

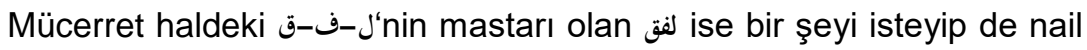
olamama anlamında kullanıımıştır. Kalıbın değişmesi ile J-ف ל-ف Jilinin anlamları da değişmektedir:

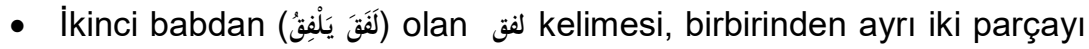
dikip birleştirmek, bir bütün haline getirmektir.

- Dördüncü babdan (لفَ lafzı ise bir şeyi elde etme ve ulaşma anlamındadır. Hatalı ve kuraldışı cümlelere الكلام الملفق müleffek kelam denilmiştir. ${ }^{3}$ Muhaddislerin ise iki farklı görüşün cem edildiği duruma telfîk ismini vermeleri ise telfîk'in ikinci babdan türeyen anlamına yöneliktir. ${ }^{4}$

Telfîk kelimesi, fıkıhta bazen sözlük anlamlarından olan birleştirme manasında da kullanılmıştır. Örneğin yemin keffaretinde on fakirin bir kısmını giydirmek kalan kısmını da yedirmek, kadının adetli ve temiz günlerini belirlemek için temiz günleri ile düzensiz adet günlerindeki temiz günlerinin birleştirmelerini ifade etmek için telfîk lafzı kullanılmıştır. İslam ülkesinde yaşayan zimmînin cizye ödeyip ödemeyeceği meselesinde de telfîk lafzı istimal edilmiştir. ${ }^{5}$

İbn Manzûr, Ebu'l-Fadl Cemâlüddîn Muhammed b. Mukrem, Lisânu'l Arab, III. Baskı, Daru Sadır, Beyrut, H. 1414, s. 330.

2 er-Râzî, Muhammed b. Ebû Bekir b. Abdulkadir, Muhtâru's-Sihâh, Mektebu Lubnan, Beyrut, 2006, s.529.

3 Heyet, el-Mu'cem'ul-Vasît, Mektebetü'ş-Şurûki'd-Duveliyye, 2004, s. 885.

4 Elbâni Muhammed Said, Umdetu't-Tahkîk fi't-Taklîd ve't-Telfîk, Dâru'l-Kâdirî, Dımeşk, 1997, s. 91-92.

5 Şîrâzî, Ebû İshâk İbrâhim b. Ali b. Yusûf, el Mühezzeb, Dâru'l-Fikr, Beyrut, 2004, II, 252. Örnekler için bkz, Şîrâzî, el-Mühezzeb, II, 252-253. 


\subsection{Istılâh Manası}

İki veya daha fazla mezhebin birbirlerine zıt olan hükümlerini belli bir işte, bir olayda cem etmektir. Örneklendirecek olursak, abdestli bir kimsenin hem mahremi olmayan kadına dokunduğu hem vücudundan kan aktığı halde birinci durumun Hanefî, ikinci durumun ise Şâfiî mezhebine göre abdesti bozmadığı hükümlerini bir araya getirip kendini abdestli sayması gibi. ${ }^{6}$

İslam hukuku alanında telif edilen eserlerde telfîk, başlıca üç anlamda kullanılmıştır.

a) İslam hukuku eserlerinde telfîk, bazen, içtihadî ihtilaftan ötürü olmayıp iki farklı hükmü birleştirerek uygulamak anlamında kullanılmıştır. Örneğin; "yemin keffaretinde on fakirin bir kısmını yedirmek diğerlerini giydirmek şeklinde telfîk yapılması caiz değildir" denirken bu mana kastedilmiştir.

b) Telfîk kelimesi bazen, bir meselede önceki müçtehitlerin söylemediği ve onların görüşlerinin ortak noktasının aksine yeni bir görüş ortaya atmaya yönelik bir manada kullanılmıştır. Daha çok icma bahsinde incelenen bu meselenin taklîd değil ictihâd ile ilgili olduğu açıktır. Buna içtihatta telfîk denilebilir.

c) Belirli bir meselede birden fazla içtihadî görüşle amel edip ortaya öyle bir durum çıkar ki; bu durumu hiçbir müçtehit kabul etmez. Böyle duruma ise "taklitte telfîk" denilmektedir. ${ }^{7}$

İlk dönemlerde fıkıh alanında yazılmış eserlerde yedinci asra kadar bildiğimiz fıkhî manasıyla telfîk lafzı kullanılmamıştır. Hatta bu dönemde İslami ilimlerde kaleme alınan diğer eserlerde de telfîk kelimesi kullanılmamıştır. ${ }^{8}$

\section{3. İçtihad Alanında Telfîk}

İçtihad alanında telfîk, iki açıdan değerlendirilebilir. Şöyle ki; iki veya daha fazla müçtehidin herhangi bir konu üzerinde içtihat ederek farklı görüşler sunup ve onlardan sonra gelen müçtehidin önceki müçtehitlerin görüşlerinden ya da doğrudan kendi görüşünü ortaya koyduğu içtihatıdır ki, bu durum önceki intilaflara olduğu gibi bu ihtilaflarda meydana gelen ortak noktaya da ters düşer. Böyle bir telfîk anlayışı şimdi sunacağımız iki sorunun açığa kavuşturulmasını gerekli kılmaktadır:

Kaya, Eyyüp Said, "Telfîk”, DiA, 2011, XL, 401.

Karaman, Hayreddin, IImihal Iman ve İbadetler, Ankara, 2006, I, 46.

8 Remuylî, Abdülkerim, Tağayyuri-ı Fetvâ bi Tağayyuri-ı l̇çtihâd, Daru'l-Kutubi'l İlmiyye, 1971, s. 256. 
a) (احداث قول ثالث) Sahabe veya herhangi bir müçtehit bir konu üzerinde iki veya daha fazla görüş sunduktan sonra, daha sonraki bir asırda başka bir müçtehit, bu görüşlerden farklı olarak üçüncü bir görüş sunabilir mi?

b) Daha sonra ki bir asırda gelen bir müçtehid, bir meselede bir başka müçtehidin, diğer ikinci bir meselede ikinci bir görüşünü alabilir mi? Bu meseleye âlimler fasıl ve tafsil adını vermektedirler. ${ }^{9}$

Ulema bu sorulara farklı cevaplar vermişlerdir. İmam Gazzâlî (ö.505/1111), üçüncü bir görüş ileri sürmenin caiz olduğunu savunmaktadır. Bir meselede bir veya iki görüş vardır demek üçüncü görüşün olmadığına işaret etmemektedir. Dolayısıyla kesin bir bilgiye sahip olunmadan üçüncü bir görüş engellenemez. ${ }^{10}$

Hanefî usûlcülerinden Pezdevî (ö.482/1089) ise: "Bir dönemde, belli bir sayıdaki görüşten başkasının ortaya çıkmaması, onlara uymayan üçüncü bir görüşün bâtıl olduğuna dair icma mahiyetinde delil kabul edilir" diyerek bunu caiz görmemiştir. ${ }^{11}$

\subsection{FasI ve Tafsil Kavramları}

Daha önce de açıkladığımız gibi fası ve tafsil; son dönem müçtehitlerin erken dönem müçtehitlerin görüşlerini alması hususuna denir. ${ }^{12}$

Hayrettin Karaman hoca müteahhir ulemadan Kadı Beydâvî (ö. 685/1286), İbnu's Sübkî (ö.771/1369), Karâfî (684/1285) gibi bazı bilginlerin bu iki konuyu (üçüncü bir görüş ileri sürme ve fasl-tafsil) ayrı konular şeklinde ele aldıklarını; Âmidî (ö. 631/1243), İbnü'l-Hâcib (ö. 646/1249), Sadru'ş-Şerî'a (ö. 747/1346), İbnü'l-Hümam (ö. 861/1457) gibi bazı usülcülerin de meseleyi tek konu şeklinde incelediklerini dolayısıyla olumlu veya olumsuz bir hükme vardıklarını ifade etmiştir. ${ }^{13}$

Bu iki usûl meselesini ayrı ayrı veya tek mesele halinde ele alanlar; mutlak caiz, mutlak caiz değil ve tafsilata tabidir şeklinde yorumlar yapıp intilaf etmişler, kısmen veya tamamen caiz değildir diyenler, delil olarak icmayı göstermişlerdir. Caiz görenler, aslında meselenin ihtilaflı olduğunu, bir iki görüşün

\footnotetext{
Karaman, İslam Hukukunda İçtihat, Ensar Neşriyat, İstanbul, 2010, s. 222.

10 Gazzâlî, Ebû Hamid Muhammed b. Muhammed, el-Mustasfâ min İlmi'I-Usûl, el-Mektebetü'lAsriyye, Beyrut, 2009, I, 199.

11 Pezdevî, Ebü'l-Hasen Ali b. Muhammed, Kenzüll-Vüsûl ilâ Ma'rifeti'l-Usûl, Dâru'lKutubi'l'İmiyye, Beyrut, III, 234.

12 Karaman, İslam Hukukunda İçtihat, s. 214.

13 Karaman, İslam Hukukunda İçtihat, s. 214.
} 
bilinmiş olmasının, daha başka görüşlerin bulunmadığına delil oluşturmayacağını, özellikle sahabe döneminden sonra bütün görüş farklılıklarını belirlemenin oldukça güç olduğunu ileri sürmektedirler. Ayrıca bu tartışmaya katılanlar, intilaflı meselenin bağlı bulunduğu konuyu bütünüyle ele almamış, cüz’i olarak yalnız sözü edilen konu üzerinde durmuşlardır. Örneğin namazın taharet rüknü ile vakit rüknünde ihtilaflar varsa bunların namaz konusunda - tek olaydaki intilaf gibi- değil, birbirinden farklı iki intilaflı mesele olarak değerlendirmişlerdir. ${ }^{14}$

\section{TAKLITTE TELFÎK}

Taklitte telfîkin gerçekleşebilmesi için bir olayda birbirine muhalif iki görüşle bir arada veya ikincisinin etkisi kalkmadan diğeriyle amel etmek gerekir. Sözgelimi, abdestin kan aldırmakla bozulmayacağı hususunda Şâfiî’yi, kadının vücuduna dokunmakla abdestin bozulmayacağı hükmünde de Ebû Hanîfe'yi taklîd eden ve bu iki taklîdin birleştiği aynı abdestin sahih olduğu kanaatinde olan kimse, telfîki gerçekleştirmiştir. Ancak iki görüşle bir arada veya aynı zamanda amel etmez de önce biriyle, başka bir zaman da diğeriyle amel eder, ikinciyle amel ederken de birinci görüşün amel üzerinde etkisi kalmamış bulunursa, bu telfîk değil, önceki mezhepten dönme ve ikinci bir mezhebe geçmedir. Bu konunun telfîk konusundan ayrı olarak değerlendirilmesi gerekir. ${ }^{15}$

\subsection{Taklitte Telfîki Caiz Görmeyenler ve Gerekçeleri}

Hanefî mezhebi fukahâsından Kâsım b. Kutluboğa (ö.879/1474), Ömer b. Nüceym (ö. 1005/1596), Ebu'l-İhlâs el-Hasen eş-Şürünbülâlî (ö.1069/1659), Alâuddîn Haskefî (ö. 1088/1677), İbn Âbidîn (ö.1252/1836); Şâfiî hukukçulardan İzzuddîn b. Abdisselâm (ö. 660/1262), İbn Hacer elHeytemî (ö.974/1567), Şemsüddîn er-Remlî (ö.1004/1596); Malikilerden Şâtıbî (ö.790/1388) taklitte telfîki caiz görmezler. ${ }^{16}$

Taklitte telfîki kabul etmeyenlerin ileri sürdükleri gerekçeler ise şöyledir:

I. Telfîkten dolayı icmâya aykırı bir durum meydana gelirse, telfîk bâtıl olur. Çünkü icmâya aykırı hükümler bâtıldır.

\footnotetext{
14 Karaman, İslam Hukukunda Içtihat, s. 215.

15 Karaman, İslam Hukukunda İçtihat, s. 225.

16 Şâtıbî, İbrahim b. Musa b. Muhammed el-Lahmî, el-Muvâfakât, Daru İbn Affân, 1997, V, 98; Karaman, Islam Hukukunda İçtihat, s. 226.
} 
II.Telfîk, mezhep müçtehitlerinin ihtilaflı hükümleri arasında olursa caiz değildir. Çünkü mezhebe bağlı diğer müçtehitlerin içtihatları da mezhep müçtehitlerinin onların içtihadına izin verdiği ve usulünü kullandırdığı için, mezhep imamının içtihadı sayılır.

III. Görüşleri birleştirilen iki imam, işlenen amelin bâtıl olduğuna söz birliği etmişlerdir.

IV. Telfîk, müslümanların icması ile bâtıldır. Telfîk, dini oyuncak haline getirmektedir. ${ }^{17}$

\subsection{Taklitte Telfíki Caiz Görenler ve Muhaliflerine Eleştirileri}

Hanefî fukahâsından Kâdî Necmeddîn İbrahim b. Ali et-Tarsusî (ö. 758/1357), Şeyhülislam Ebu's-Suûd (ö. 981/1574), Zeynüddîn b. Nüceym (ö. 970/1562), Muhammed Emin (ö. 987/1579); Mâlikî hukukçulardan Muhammed b. Ahmed ed-Düsûkî (ö. 1230/1815) ve Şah Veliyyullah Dehlevî (ö. 1180/1766) gibi âlimlerde telfîki caiz görürler. ${ }^{18}$ Bunlara göre şart ve cüzleri bulunan bir amelin bütün bu şart ve cüzlerinde belli bir müçtehide tabi olmanın gerekliliğini ifade eden ne bir nass, ne icmâ, ne de sağlam bir kıyas vardır. Dinin delil ve kaynaklarının gerekli kılmadığı hiçbir şey, farz ya da vacip olamaz. Ayrıca hiçbir âlim, telfîkin haram olduğunu söylememiştir. ${ }^{19}$

Telfîki caiz görmeyenleri de şu zikredeceğimiz hususlardan ötürü de eleştirmişlerdir:

- Burada sözü edilen icmâ, usulün konusu olan icma değildir. Anlatmak istedikleri, bir konuda farklı görüşler ortaya çıktıktan sonra, daha farklı bir görüşün ileri sürülmemesinin sukûtî icmâ anlamına gelmesi ve bunun yeni bir görüşün bâtıl olacağına delalet etmesidir. Bu tür bir icmanın delil olması kesin olmadığı gibi, böyle bir icmânın sübutu da mümkün değildir. ${ }^{20}$

- Her müçtehit ister müstakil ister müntesip olsun, görüşü diğer müçtehitlerin görüşüne muhalif olursa, kendi içtihadına uyar. Bütün müçtehitlerin

17 Karaman, İslam Hukukunda Içtihat, s. 228.

18 Düsûkî, Şemseddin Şeyh Muhammed Urfa, Haşiyetü'd-Desûkî ala Şerhi'l-Kebir, Daru İhyai'lKütübi'l-Arabiyye, Kahire, ts, I, s. 20.

Zuhayli, Vehbe, el-Fıkhu'I-İslâm ve Edilletuhu, Daru'Fikr, Dımaşk, 1986, I, 109; Ölmez, Sadi, Mezhepler Arası Telfik ve Ulemanın Telfik Ille Illgili Görüşleri, Yüksek lisans Tezi, YYÜ, 2016, s. 39.

19 Abdurrezzâk Ahmed Senhurî, "et-Telfîk beyne Ahkâmi'l-Mezâhib”, el-Mü'temeru'l-Evvel liMecme'i'l-Buhûsi'l-İslamiyye, s. 67-69.

20 Senhurî, et-Telfîk beyne Ahkâmi’l-Mezâhib, s. 83. 
ana kaynağı Kur'ân ve Sünnet olduğuna göre, mezhep müçtehitleri arasında caiz olan telfîk, genel olarak da caizdir. ${ }^{21}$

- Görüşleri birleştirilen iki imam, işlenen amelin bâtıl olduğunda söz birliği etmişlerdir" sözü tutarlı değildir. Çünkü her imam, "Bu amel görüşüme muhalefet edilen noktada bana göre bâtıldır" diyebilir; fakat "Diğer imama göre de bâtıldır" diyemez. Ona göre bâtıl olan amel, diğer imama göre sahihtir. ${ }^{22}$

- İcmâ ehli müctehidlerdir. Telfîk konusu, müçtehitler döneminden sonra, yedinci yüzyılda ortaya atılmış ve mukallidler arasında tartışma konusu olmuştur. Böyle olunca, "Telfîk, müslümanların icması ile bâtıldır" demek, cüretli ve isabetsiz bir sözdür. ${ }^{23}$

- Zaruret halinde yapılan telfîkte, dinin oyuncak haline getirilmesi söz konusu olamaz. Çünkü oyuncak haline getirilmesi için bir art niyet olması gerekir. Böyle bir şey de burada söz konusu değildir.

Gerek içtihat ve gerekse taklîd yoluyla telfîk meselesi, müçtehitler devrinin sonuna kadar tartışma konusu olmamıştır. Bununla beraber selef devrinde, uygulamada telfîk görülmüş, ayrıca bir mezhebin müçtehitlerinin görüşleri arasında telfîk genelde câiz görülmüştür. Taklîd yoluyla yapılan telfîki yasaklayan şer'î ve muteber bir delil olmadığı için iyi niyetle yapılan ve nasların lafız ve ruhuna aykırı olmayan telfîkin caiz olmadığını savunanların delilleri zayıf kalmaktadır. ${ }^{24}$

\subsection{Bir Meselede Meydana Gelen Telfîk}

Herhangi bir meselede iki farklı mezhebin görüşünü alıp amel etme hususunda ulema ihtilaf etmiştir. Kimisi tek meselede telfîk olduğu için yapılan amelin batıl olduğunu savunurken; kimisi de böyle bir meselede ihtilaf olduğu için batıl olduğu kanısına varmanın doğru olmadığını ifade etmiştir.

İzmirli İsmail Hakkı, İlm-u'l-Hilâf adlı kitabında hususla ilgili şunları söyler. "Dinin füru' kısmında taklidi caiz görenlerin önüne bir de "telfîk" meselesi çıkıyor. Telfîk; iki mezhebi bir araya getirerek amel etmek demektir. Telfîk, bir veya iki hadisede olmak üzere iki türlüdür. Bir hadisede olan telfîk oyundur, ittifakla men edilmiştir. Mesela abdestli olan bir kimsenin vücudundan kan aktığında ve bir kadına dokunur sonra da namaz kıldığında bu kişi, Hanefi ve

21 Ebû Leys Semerkandî, Te'sisü’n-Nezâir fi'l-Hilaf, Süleymaniye Kütüphanesi, Şehit Ali Paşa Kasım, s. 9.

22 Ölmez, Mezhepler Arası Telfik, s. 40.

23 Senhurî, et-Telfîk beyne Ahkâmi'l-Mezâhib, s. 83.

24 Karaman, İslam Hukukunda İçtihat, s. 220. 
Şâfii mezheplerine göre telfîk yapmış olur. Buradaki telfîk bir hadisede (bir namazda) olduğu için geçersizdir, namaz sahih değildir. Aynı şekilde bir namazda başın bir kısmını mesh etmek konusunda Şâfiî̀yi köpeğin temizliği konusunda Malik'i taklîd etmek, mezhepleri birbirine karıştırmak ve oynamak olduğundan bunlar, geçersiz sayılmıştır."25

\subsection{Birden Fazla Meselede Meydana Gelen Telfik}

Tek meselede gerçekleşen telfîkte ulema arasında intilaf olduğu gibi, bu hususta da âlimler intilaf etmişlerdir. Ama tercih edilen görüşe göre ve mütteahhir ulemanın yaptığı tercihe göre de birden fazla meselede telfîk gerçekleşmesi durumunda dahi amel etmek caizdir.

İslam tarihine bakıldığında Müslümanlar sahabîye gelip soru sorduklarında hep aynı sahabeye soru sormuyorlardı. Bilakis farklı farklı sahabîye soruyorlardı ve aldıkları cevaba göre de amel ediyorlardı. Bilindiği üzere sahabe efendilerimizin birbirlerine muhalif görüşleri de vardı. Müslümanların sahabeye soru sorup onların verdiği farklı fetvalarla amel etmesi karşısına kimse de itiraz etmemiştir. Bundan dolayı da birden fazla meselede telfikin gerçekleşmesi durumunda hüküm bozmadıktan sonra caizdir. ${ }^{26}$

Belli bir mezhebe bağlı olan kişinin gerektiğinde başka bir mezhebi taklîd edip, etmemesi hususunda üç farklı görüş vardır:

1. Belli bir mezhebe bağlanan o mezhebi kabul etmiş ve görüşlerini kendince doğru bulduğundan, başka bir mezhebi taklit edemez. Bundan dolayı da kendi mezhebinin dışına çıkamaz.

2. Bir mezhebe bağlı olan bir kimse başka bir mezhebe uymasında herhangi bir sakınca yoktur. İnsanlara bir şeyi yaptırmak veya yasaklamak Allah ve Resulünün emriyle ancak söz konusudur. Oysaki Allah Resulü hayatta iken insanlara belli bir mezhebe uymalarını zorunlu kılmamıştır. Dolayısıyla bir kişi istediği mezhebi taklîd edebilir. ${ }^{27}$

3. İbnü'l-Hümâm bu meselede farklı bir yorumda bulunarak şöyle söylemiştir: Kişinin belirli bir meselede kendisini bağlayacak şekilde belli bir mezheple amel etmesi, bu konuda görüş bildiren başka bir mezheple amel etmemesini gerektirir. Bağlı bulunduğu mezhebin belli bir kısım görüşüyle amel etmiyorsa, başka bir mezhebin bu mevzudaki fetvasına uymada herhan-

25 İzmirli, İsmail Hakkı, İImu'l-Hilâf, Darı Saadet, İstanbul, 1912, s. 280-281.

26 İzmirli, İlmu’l-Hilâf, s. 281.

27 İzmirli, İlmu’-Hilâf, s. 281. 
gi bir beis yoktur. Çünkü kendisini bağlayan bir mezhebe uymasını gerektirecek herhangi bir husus, fıkıhta mevcut görülmemiştir. Fıkhın üzerinde durduğu tek vücub, herhangi bir âlimi tahsis etmeksizin onlara ittibayı emretmesidir. ${ }^{28}$

İzmirli İsmail Hakkı, bu konu hakkında şöyle söylemektedir: "Halkın belirli bir mezhebe göre amel etmesi caizdir; taklîd ettiği imamın mezhebine uymayan bir içtihada birbirine zıt iki hüküm ile amel eder, böyle yapınca, başka bir imamı taklîd ederek yaptığı ameli iptal etmemiş olur; çünkü fiilin yapılıp bitmiş olması, hâkimin hükmü gibidir, bir sonraki amel onu iptal etmez. Bundan dolayıdır ki, bir gün Şâfiî mezhebine, diğer gün de Maliki mezhebine göre namaz kılması caizdir."29

\section{3. İki Görüşten Kolay Olanı Alma}

Söz konusu bir meselede iki görüş olup, bu görüşlerden kolay ya da zor olanı tercih etme hususunda âlimler ihtilafa düşmüşlerdir.

a) İki görüşten en zor olanını almak kıyas yoluyla fıkha muhaliftir. Çünkü Allah zengin, kul ise daima muhtaçtır. Nitekim Allah-u Teâlâ şöyle buyurmaktadır: "O sizin için kolaylık ister..."30 yine başka bir ayeti kerime de " Sizin için dinde zorluk kılmamıştı"'31 buyurmaktadır. Hz. Peygamber (s.a.v) de "Zarar vermek ve zarara zararla karşılık vermek yoktur"32 ve başka bir hadiste de "Müsamaha dini olan Hanif din ile gönderildim"33 buyurmaktadır. Bu delillerde göstermektedir ki iki görüşten kolay olanı hangisi ise onu almak gerekir.

b) İki görüşten en hafifini tercih etmek ve bunu da "Din müsamahadır" diyerek deliller dinmek pek doğru değildir. Çünkü mükellefiyetin bizzat kendisinde zorluk vardır. Eğer dinin müsamaha olduğunu genel olarak alacak olursak insanoğlunun mükellefiyetini kaldırmakta daha iyi olurdu. Dinde müsamahadan, ancak bir meseleyi aslına rücu ettirip ve o meselede nefsi arzular amaçlanmıyorsa, o zaman bahsedilebilir. ${ }^{34}$

28 İbnü'l-Hümâm, Kemâlüddîn Muhammed b. Abdilvâhid b. Abdilhamîd es-Sivâsî, Şerhu Fethi'lKadîr, Dâru'I-Kutubi'l-İlmiyye, Beyrut, h. 1316, XVI, 319; Zuhayli, Vehbe, Mezhep Hükümlerinin En Kolayını Almada Kurallar, (trc: M. Nuri AKTAŞ), İslam Hukuku Araştırmalar Dergisi, sy. 7, Nisan 2007, s. 402.

29 İzmirli, İlmu’l-Hilâf, s. 282.

30 Bakara, 2/185.

31 Hac, 22/78.

32 İbn Mâce, "Ahkâm", 17.

33 Ahmed, "Müsned", 11616.

34 Şâtıbî, Ebû İshak İbrahim b. Musa, el-Muvâfakât, Müsessetü-Risale Naşirun, I. Baskı, Beyrut, 2013, IV, 480- 481. 


\section{4. Üçüncü Bir Görüş îhdas Etme}

Daha önceki dönemlerde müçtehitlerin vardığı iki farklı görüşten ayrı olarak, daha sonraki asırda gelen bir müçtehidin, aynı meselede üçüncü farklı bir görüş ortaya koymasına denir. ${ }^{35}$ Şöyle ki; ölen bir kimsenin dedesi ve kardeşlerinin mirastaki payları hakkında âlimler iki farklı görüş belirtmişlerdir. Hanefi ve Hanbeliler, dede ve kardeşin aynı miras payına sahip olduklarını; cumhur ise, dede ve kardeşin mirastaki paylarının farklı olduğunu söylemiştir. Bu iki görüşten farklı olarak İbni Hazm, kardeşlerin olması durumunda dedenin mirastan pay alamayacağını bazı âlimlerden nakletmiştir. ${ }^{36}$ Örnekten de anlaşılacağı üzere önceki dönemlerde iki farklı görüş ileri sunulduktan sonra, daha sonra ki dönemde üçüncü farkıı bir görüş ortaya atılmıştır.

Âlimler böyle bir durum meydana gelmesi halinde üçüncü görüşün caiz olup, olmadığı hususunda üç farklı görüş beyan etmişlerdir.

- Müçtehitler bir konu hakkında iki farklı görüş beyan etmişlerse bu konu hakkında âlimler icmâ etmiş sayılmaktadırlar. Üçüncü bir görüş indas etmek ise icmâya muhalif olacağından caiz değildir. Bu görüş çoğu usûlcülerin görüşüdür. ${ }^{37}$

- Ulema bir konu hakkında iki farklı görüş sunmaları icmâ sayıııyorsa, aynı meselede üçüncü bir görüş sunmak da icmâ sayılmaktadır. Nitekim içtihat kapısı da açıktır. Bu da üçüncü görüşün ihdas etmesinin caiz olduğuna işarettir. Bu görüşü savunan ise Zahirîlerdir. ${ }^{38}$

- İhdas edilen üçüncü görüş kendisinden önceki iki farklı görüşün hükmünü ortadan kaldırmıyorsa caiz olup, hükmünü ortadan kaldırıp, nesh etmesi durumunda caiz değildir. ${ }^{39}$

Anlaşıldığı üzere telfîk, üçüncü bir görüş indas etmeye çok benzemektedir. İsnevî, "Telfîk meselesinde doğru olan, eğer iki görüş arasında gerçekleşiyorsa üçüncü görüş indas etmekten hiçbir farkı yoktur" diyerek telfîk ile

35 Serahsî, Ebû Bekir Muhammed b. Ahmed, Usûlü's-Serahsî, Dâru'l-Ma'rife, Beyrut, 2005, S. 310.

36 el-Kurtubî, Ebû Muhammed Alî b. Ahmed b. Saîd b. Hazm el-Endelüsî, el Muhallâ bil Asâr, Daru'l-Kutubi'l-İlmiyye, Beyrut, 2010, VIII, 307.

37 el-'Atibî, et-Telfîk beyne'l-Mezâhib, s. 14.

38 İbn Hazm, Ebû Muhammed Ali b. Ahmed b. Said b. Hazm, el-Endelüsî ez-Zahirî, el-Ihkâm fi Usûli'l-ahkâm, Mektebetü'l Asriyye, Beyrut, I, 560.

39 Şirâzî, et-Tabsire, s. 390. 
üçüncü bir görüş indas etme arasında herhangi bir fark olmadığını ifade etmiştir. ${ }^{40}$

Telfîk ile üçüncü görüş ihdas etme hususlarının birbirinden ayrıldığı noktalar ise şunlardır:

1) Telfik iki farklı mezhebin görüşlerini birleştirme ve bu mezheplerden bağımsız olmayıp ortaya çıkan sonuçtur. İhdası kavli salis ise, önceki mezheplerin hükümlerini nesh edip yeni bir görüş ortaya koymaktır.

2) Telfîkte önceki iki farklı görüşün tamamı alınır. Diğerinde ise bir kısmı alınır.

3) Telfîk iki farklı görüş arasında olduğu gibi birkaç farklı görüş arasında da yapılabilmektedir. İhdası kavli sâlis ise sadece iki farklı görüş arasında yapılabilmektedir. ${ }^{41}$

\section{Mezhepler Arası Telfîk}

İslam uleması telfîkin mezhepler arasında caiz olup olmayacağı hususunda intilafa düşmüşlerdir. Kimileri mezhepler arasında telfîki caiz görürken, kimisi de batıl görmektedir. Biz bu intilafı üç farklı görüş altında inceleyebiliriz:

1) Âlimlerin büyük çoğunluğunun savunduğu görüş mezhepler arası telfîkin caiz olmadığı yönündedir.

Şafii âlimlerinden İbn Hacer el-Heytemî, el- Fetava adlı eserinde müteahhir Şâfii ulemasınca mezhepler arası telfikin batıl olduğunu söylemiştir. ${ }^{42}$ Hanefi ulemasından el-Haskefî ise mezhepler arası telfîkin caiz olmadığı hususunda icmanın olduğunu belirtmiş ve böyle bir telfikin batıl olduğunu söylemiştir. ${ }^{43}$

Kudûrî’nin tahkikinin önsözünde Hafız Kasım der ki, "Usulcüler şöyle demiştir: Bir hususta iki farklı içtihattan mürekkep bir şekilde taklitte bulunmak sahih değildir. Bu hususta icma vardır." yine bu eserde "Telfik edilmiş bir hüküm Müslümanların icma-ı ile batıldır."44

40 el-İsnevî, Abdürrahim b. Hasan, Süllemü'l-Vusûl Şerhu'n-Nihâye 's-Su'l, Daru'l Kutubi'l İlmiyye, Beyrut, 2009, IV, 629.

41 el-'Atibî, et-Telfîk beyne'l-Mezâhib, s. 16.

42 el-Heytemî, Şihâbuddîn b. Ahmed b. Muhammed b. Ali İbn Hacer, el Fetâva'l-Fıkhiyye elKübrâ, Daru's-Sadr , Beyrut, 1997, 225.

43 el-Haskefî, Muhammed b. Ali, ed-Dürrü'l-Muhtâr Şerhu Tenvîri'l-Ebsâr, Daru'l Kutubi'l İlmiyye, Beyrut, 2002, I, 75.

44 Ölmez, Mezhepler Arası Telfik, s. 58. 
Telfîkin caiz olması durumunda fıkha bir nevi halel gelir. Hiç şüphesiz velisiz evlenen biri, Hanefi mezhebini taklit ettiğini söyler, şahitsiz evlenen biri ise maliki mezhebini taklit ettiğini söyler ve böylece İslam toplumunda kötülüğün ve mefsedetin yolu açılmış olur, bu da şer'an yasaktır. Söylediklerimizi onaylayacak bir tarihi vakayı el-'Atıbî telfîki emelleri doğrultusunda kullanan Arap şairi Ebû Nüvas'tan (ö.198/813) şöyle aktarmaktadır: “Ebû Hanife nebîzin ${ }^{45}$ helal olduğunu söylemiştir. Îmâm Şâfiî ise nebîz ile içkinin aynı şeyler olduğunu söylemiştir. Bu durum da içki yani (hamr) helaldir." 46

Telfîkin caiz olmadığın savunun âlimler, bu görüşlerini sedd-i zerâî ilkesine dayandırmaktadırlar. Telfîkin caiz olması durumunda bu yöntem sadece mukallidin daha az yükümlülük getiren hükümler elde etmek amacıyla kullanacağı bir araca dönüşecek, bu durumda yalnız mezhepler değil aynı zamanda fıkhın değişmez hüküm ve gayeleri de zarar görecek, nihayetinde İslâm'ın ortaya koyduğu nizamın tamamen işlevsiz kalacağı bir toplum ortaya çıkacaktır. ${ }^{47}$

2) Maliki müteahhir fukahâsı telfîkin mutlak olarak caiz olduğunu söyler. Nitekim Derdîr'in (ö. 1201/1786) eş-Şerhu'l-Kebîr aslı eserine haşiye yazan Cevaz b. Arafa el-Malik bunu sahih görür. Desûkî de mezhepler arası telfîkin caiz olduğunu tercih eder. Emir el-Kebir de hocalarından telfîkin caiz olduğunu geniş bir şekilde nakleder. ${ }^{48}$

Ayrıca telfîki reddettiğimiz vakit avam tabakayı meşakkat ve zorlukla baş başa bırakmış oluruz. Tek bir mezhebe bağlı kalındığında o mezhebe göre amel etmediğinde günah kazanmış olur. Günlük yaşantıya baktığımızda hiçbir muamelatta tek bir mezhebe bağıılığı nerdeyse bulmak imkânsızdır. İnsanlara tek bir mezhebin hükümlerini dayatmak onlar için bir zorluk olur. Oysaki mezheplerde müminler için rahmet vardır. ${ }^{49}$

45 Kuru üzüm, hurma, bal, arpa, buğday vb. şeylerin suda bekletilerek onu tatlandırması yolu ile elde edilen bir içki çeşidi. Sarhoş etsin veya etmesin aynı adla anılır. Nitekim nebîze şarap (hamr) dendiği gibi, üzüm suyundan elde edilen şaraba da nebîz denmektedir. Bk, Heyet, elMu'cemu'l-Vasît, s. 897.

46 el-'Atibî, et-Telfîk beyne'l-Mezâhib, s. 27.

47 Kaya, "Telfîk", XL, 401-402.

48 Zuhayli, Mezhep Hükümlerinin En Kolayını Almada Kurallar, s. 412.

49 Halid Hasan, el-Kavlu's-Sedîd fî Ba'zi Mesâil'il-Íctihâd ve't-Taklîd, yy., Suudi Arabistan, 2006, s. 94. 
Telfîk ile taklit birbirleriyle yakın ilişki içerisindeler. Telfîki taklidin bir alt kısmı olarak da değerlendirebiliriz. Dolayısıyla taklidi caiz görenler, telfiki de caiz görmelidir. ${ }^{50}$

3) Telfîkin hükmüyle ilgili âlimlerin sunduğu üçüncü ve mutedil görüş ise bazı şartlara haiz olması halinde telfîk caizdir. Bu şartlar ise şunlardır:

- Telfîk yapılan mesele, âlimlerin icma ettikleri meseleye muhalif olmamalıdır.

- Şer'î olan bir hükmü nesh etmemeli veya hükmü iptal etmemelidir.

- Hiçbir delil gözetmeksizin, kendi arzularını tatmin etmek için diğer mezheplerin en kolayını almamalıdır.

- Telfîk bir maslahat, zaruret veya bir intiyaca binaen olmalıdır. Zaruret olmadan başka bir mezhebin görüşü alınmamalıdır. ${ }^{51}$

\section{DÖRT BÜYÜK MEZHEBIN TELFIKE BAKIŞI}

Telfîk ile ilgili İslam hukukçularının görüşlerini üç farklı görüş altında inceledik. Şimdi de dört mezhebin telfîk ile ilgili görüşlerini ele alacağız.

\section{a. Hanefi Mezhebi}

İbnü'l Hümâm (ö. 861/1457) et-Tahrir adlı eserinin Tetebbu' Ruhas bahsinde şöyle söylemektedir: "Mesela kim abdestte ovalama hususunda Şâfii mezhebini, şehvet olmadan bir kadına dokunmada abdest bozulmayacağı hususunda da Mâliki mezhebini taklit edip namaz kılarsa, abdestte ovalama işlemini yapmışsa namazı sahihtir. Aksi takdirde her iki mezhebe göre namazı batıldır." 52 Muhammed Emin Padişah et-Tahrir üzerine yaptığı şerhinde bu görüşe katılmamaktadır. Telfîk konusunda müçtehitlerin hepsi telfîkin sıhhati için aynı şartı koşmamıştır. Zira ileri sürülen birbirinden farklı şartlar, birbirine zıt olabilmektedir. Böyle olması halinde nasıl olur da telfîk yapılan bir meselenin butlanına hüküm verilebilir. Çünkü bazı âlimlerin şartları diğerlerine göre daha kolay veya daha zordur. İhtilaflı olan bir meselede kesin bir yargıya varmak doğru değildir. Dolayısıyla telfîk yapılan bir meselede yapılan amelin batıl olduğunu söyleyen kimsenin de delil getirmesi gerekir. ${ }^{53}$

\footnotetext{
50 Zeybârî, Amir Saîd, Mebâhis fî Ahkâmi'l-Fetâvâ, Beyrut, 1995, s. 94.

51 Remuylî, Tağayyuru-l-Fetvâ, s. 265-266.

52 İbnü'l Hümâm, et-Tahrir fi Usûli'l Fıkh, Daru'l Kutubi'l İlmiyye, Beyrut, IV, 254

53 Muhammed Emin Padişah, Teysîru't-Tahrîr, Daru'l Kutubi'l İlmiyye, Beyrut, IV, 255.
} 
İbn Abdü'ş-Şekûr Müsellumu's-Subût adlı eserinde “İcma yoluyla İhdasu kavli salisin yasak olduğu açık olduktan sonra, bir meselede telfîk yapmanın caiz olmadığı kanısındayım." 54

Murûvî el-Kavlü's-Sedîd adlı eserinde "zamanın ulemaları arasında taklitte telfîkin caiz olmadığına dair görüşler çoğaldı. Yalnız taklitte telfîkin caiz olmayışına dair bir delile rastlamadım" şeklinde görüş beyan etmiştir. ${ }^{55}$

İbn Âbidîn (ö. 1252/1836) ise telfîkin hükmünün icmaen batıl olduğunu söylerken konuya dair ise şöyle bir misal getirir: "Mesela bedeninde kan akan birisinin Şâfii mezhebini taklit ederek namaz kılması, yabancı bir bayana dokunan birinin Hanefi mezhebini taklit etmesi durumunda, her iki durumda da namazı batıldır." 56

Hanefi uleması telfîkin hükmünde ihtilafa düşmüşlerdir. Kimisine göre telfîk icmâya muhalif olmasından ötürü batıl iken; kimilerine göre de telfîkin hükmünün batıl olmayıp caizdir. Ancak Hanefi ulemasının çoğunluğunun görüşüne baktığımızda daha önce de açıklamış olduğumuz şartların gerçekleşmesi halinde telfîkin caiz olduğu kanısındadırlar. ${ }^{57}$

\section{b. Mâliki Mezhebi}

Karâfî (ö. 684/1285) Şerhu Tenkîhi'l Fusûl adlı eserinde şöyle der: "Zaruri durumlarda mezhepleri taklit üç şartla caizdir. İcmâya muhalif olacak bir şekilde aralarında cem yapılmamalıdır. Mesela mehirsiz, velisiz ve şahit olmadan yapılan evlilik gibi. Çünkü böyle bir şeyin uygulanabilirliğini kimse söylememiştir." 58 Karâfî 'nin verdiği örnekteki telfîk yasaklanmıştır. İbn Cizî de Karâfî'nin dediği gibi icmâya muhalif olması halinde telfîkin caiz olmadığını, intiyaç anında telfîkin caiz olduğunu vurgulamaktadır. ${ }^{59}$

Sa'îdî, Şefşâvenî'nin (ö. 986/1578) telfik ile ilgili şu ifadelere yer verdiğini açıklar: "Maliki mezhebinde muhaliflerin delillerini gözetmek telfik sayılmaktadır. Mesela Şiğar akdinin caiz olmadığına dair delil hadis ve kıyastır. Bu

54 Muhibullah b. Abduşekûr el- Hindî, Musellemu's-Subût, Matbaatu Bûlâk, 1. Baskı, 1322, II, 407.

55 el- Murûvî, Muhammed b. Abdülazim Kavli Sedîd fî Ba'zi Mesâilil-lictihâd ve't-Taklîd, (Thk: Câsım Yasin), Daru-Da'vet, Kuveyt, 1. Baskı, 1408, s. 79.

56 İbni Abidîn, Seyyid Muhammed Emin b. Ömer b. Abdülaziz, Haşiyetu Reddi'l Muhtâr âle'dDüreri'l- Muhtâr, Matbaatu Mustafa Elbanî el- Halebî, 2. Baskı, Mısır, 1386, I, 75.

57 es-Sa'îdî, Abdullah b. Muhammed b. Hasan, et- Telfîk ve Hukmuhu fi'l Fıkhi'l İslamî, yy., s. 26.

58 el- Karâfî, Ebu'l Abbas Şihâbuddîn Ahmed b. İdris b. Abdurrahman el- Malikî, Şerhu Tenkîhi’Fusûl, (Thk: Taha Abdürraûf), Daru'l Fikr, 1. baskı, Kahire, 1393, s. 432.

59 es-Sa'îdî, et- Telfîk, s. 27. 
delillere dayanarak İmam Malik bu akdin feshine hükmetmiş, Ebu Hanife'de akdin feshine hükmetmemiştir. İmam Malik'e göre Şiğar akdi ne zaman meydana gelmişse bilindiği zaman fesh edilir. ${ }^{60}$

Hanefi mezhebinde olduğu gibi Maliki mezhebinde de telfîki caiz görenler olduğu gibi az da olsa caiz olmadığını savunan âlimler de vardır. Caiz olduğu kanaatinde olanlar ise genellikle belli şartlarla telfîki caiz görmüşlerdir.

\section{c. Şafii Mezhebi}

İbn Hacer el-Heytemî el-Fetava adlı eserinde şöyle söyler: "Delilleri bilmeyen bir kişi ruhsatlara uymadığı veya uyduğu mezhepte hiçbir ulemanın tasvip etmediği bir telfîk meydana gelmediği müddetçe, Şafii, Maliki veya diğer mezhep imamlarını taklit edebilir."61

Yine İbn Hacer telfîkle ilgili şöyle söyler: "Müslümanların icmasıyla telfîkin hükmü batılır. Mesela abdest alan birinin başını mesh ederken Şafii mezhebini taklit ederek başın bir kısmını mesh etmesi, daha sonra bedenine bir necaset isabet ettiğinde necaset miktarı ile ilgili olarak da Maliki mezhebine tutunması gibi. Böyle bir telfîk batıldır. Çünkü hiçbir müçtehidin onaylamadığı iki görüşü birleştirip, ortaya koymuştur. Çünkü Şafii mezhebine göre necaset olduğunda abdest geçersizdir. Maliki mezhebine göre de başın hepsi mesh edilmediğinden dolayı abdest geçersizdir. ${ }^{62}$

Başka bir yerde de İbn Hacer şöyle söylemektedir: "Kim bir meselede bir imamı taklit ederse o meseleyle alakalı bütün şeyleri bilmesi gerekir. Telfîk yapması da caiz değildir. Örneğin; kim köpeğin temiz olduğu konusunda Maliki mezhebini taklit ederse, Maliki mezhebinin neyi necis kabul edip etmediğini bilip, uyması gerekir. Şayet Maliki mezhebinden köpeğin necis olmadığını alırsa, Şafii mezhebinden abdeste başın bir kısmını mesh edip namaz kılsa namazı batıldır. Çünkü sadece imam Şafii'nin görüşüyle amel etmemiştir. İki mezhep arasında telfîk yapmıştır. Ne zaman ki taklitte telfîk meydana gelirse, taklit batıl olduğu gibi telfîk yaptığı mesele de icma'en geçersiz olur."63

\footnotetext{
60 es-Sa'îdî, et- Telfîk, s. 10.

61 el-Heytemî, el Fetâva'l-Fıkhiyye el-Kübrâ, I, 251.

62 es-Sa'îdî, et- Telfîk, s. 29.

63 el-Heytemî, el Fetâva'l-Fıkhiyye el-Kübrâ, c. VI, 76.
} 
Helvanî el-Vesm fil-Veşm adlı risalesinde telfikle ilgili şu sözlere yer vermektedir: “Telfîkin caiz olmamasının şart koşulması kesinleşmiştir. Bu bizim, Hanefilerin ve Hanbelilerin tercih ettikleri görüştür."64

Sa'îdî, Bulkîni'nin (ö. 824/1421) telfîki iki bir meselede meydana gelen telfîk, iki meselede meydana gelen telfîk şeklinde iki ayrı kategoride ele aldığını aktarmaktadır. ${ }^{65}$

Dimyâtî (ö.1300/1883), ise Şâfiî Fakihlerinden İbn Zeyâd'ın konuyla ilgili şu sözlerine yer vermiştir: "Telfiği zedeleyip yasaklayan durum tek meselede olmasıdır. Mesela mahremi olmayan bir bayana dokunup Hanefi mezhebini taklit ederek abdest alan bir kimse ve aynı meselede kan aldırırken Şafii mezhebini taklit eden kimsenin kılığı namaz batıldır. Çünkü her iki imam da böyle bir durumda namazın batıl olduğuna ittifak etmişlerdir. İki meselede meydana gelen telfîk ise birinci meselenin hilafına olup taklit edilmesinde herhangi bir sakınca yoktur. Mesela Şafii mezhebini taklit ederek başın bir kısmını mesh eden bir kimse, namaz kılacağı vakit kıble konusunda Hanefi mezhebine uyması halinde namazı sahihtir. Çünkü burada imamların namazının batıl olduğuna dair bir ittifak söz konusu değildir. Bir de iki ayrı meselede meydana geldiği için namazın sıhhatine mâni olmayıp, taklit edildiği takdirde herhangi bir sakıncası yoktur."66

Şafii mezhebinde müteahhir ulemadan çoğu telfîkin caiz olmadığı görüşündedir. Caiz olduğunu savunanlarda tek meselede hâsıl olan telfîki caiz görmeyip sadece iki farklı meselede meydana gelen telfîki caiz görmektedirler. İfade ettiğimiz gibi de bu görüşte olan sayısı azdır. Ulemanın ekseriyeti telfîkin caiz olmadığı görüşündedir.

\section{d. Hanbeli Mezhebi}

Hanbeli mezhebinin usûl eserlerinde telfîk ile ilgili bir malumata rastlanılmadığı için, füru eserlerinde telfîk ile ilgili örnekler vererek, Hanbeli mezhebinin telfîke olan bakış açısını açıklamaya çalışacağız. ${ }^{67}$

Merdâvî (ö. 885/1480), Ebû Yê'lâ es-Sağîr'den yaptığı nakilde konuyla ilgili şu sözlere yer vermiştir: "Yolculuk yapan bir kadın ve erkek zina etme

64 el-Helvanî, Şihâbuddîn Ahmed b. İsmail, el-Vesm fil-Veşm, (Thk: Ahmed Berrak), Matbaatu Nercis, Riyad, 1426, s. 133.

65 es-Sa'îdî, et- Telfîk, s. 31.

66 ed-Dimyâtî, Ebû Bekr Osman b. Muhammed Şettâ el-Bekrî, lânetu-Talibîn, Daru'l Kutubi'l İlmiyye, 1. Baskı, Beyrut, 1415, IV, 360.

67 es-Sa'îdî, et- Telfîk, s. 32. 
endişeleri varsa dahi yanlarında veli ve şahit yoksa evlenemezler."68 Ancak Ebû Yêlâ 'nın görüşünü nakleden müellif bu görüşe itiraz etmektedir. Hanbeli mezhebinde zahir olan görüşe göre zina korkusu olması halinde telfikin caiz olmasıdır. Çünkü nikâhta veli olup olmama meselesi ulema arasında ihtilaflı bir mesele olup, zina ise en büyük günahlardandır. Yani zinanın hükmünde ulema arasında herhangi bir ihtilaf söz konusu bile değildir. Böyle olması halinde hükmü kesin olan bir şeye hükmünde ihtilaf edilen bir mesele tercih edilemez. Bundan dolayı da zina korkusu olan bir kadın ve erkek velisiz evlenebilirler. ${ }^{69}$

Sefârînî, telfîk ile ilgili risalesinde şu sözlere değinmiştir: "Bana göre telfîk caiz değildir. Çünkü telfîkte mefsedet vardır. Şayet telfîk kapısı açık olsaydı İslam fıkhı bozulur bütün haram olan şeyler telfîk aracılığıyla helal sayılırdı."70

Hanbelilerden Şattî (ö. 1882-1959) ise şöyle der: "Nikâh konusu hakkında Şeyh Osman en-Necdî'ye soru ve cevaplar yöneltildiğini gördüm. O da bu sorulara şöyle cevap verdi. Hanefi mezhebine göre evlenen bir kimse, nikâhla ilgili bütün meselelerde (hul', talak vb.) Hanefi mezhebine uyması gerekmektedir. Ta ki taklitte telfîk meydana gelmesin. Bu da tasvip edilmeyen ve doğru olmayan bir şeydir."71

Hanbeli mezhebi de telfîk olayına mesafeli davranmıştır. Diğer mezheplerde olduğu gibi bu mezhepte de telfîkin hükmünde ulema kendi aralarında intilaf etmişlerdir. Ama sonuç olarak şu anlaşılmaktadır ki; Hanbeli mezhebi zaruret, ihtiyaç ve maslahata binaen telfîki caiz görmüştür.

\section{RUHSATLARA UYMA VE TELFIK İLişKISi}

Ruhsat sözlükte, bir işte kolaylık ve esnekliğin olması manasına gelmektedir. ${ }^{72}$ Fıkıh usulü terimi olarak ise, şer'an geçerli özürlere binaen normal durumlara ait aslî hükmün (azîmet) gereğine uymamayı caiz kılan, kolaylaştırma esasına dayalı geçici hükmü ifade eder. Mesela susuzluktan ölecek

68 el-Merdâvî, Alâuddîn Ebu'l Hasan Ali b. Süleyman, El-İnsaf Fi Marifeti er-Râcih mine'l Hilâf, (Thk: Abdullah Türkî), Daru'l Hicret, 1416, s. 172.

69 es-Sa'îdî, et- Telfîk, s. 33.

70 Sefârînî, Muhammed b. Ahmed, Risaletu Sefârînî fil Telfik, (Thk: Abdülaziz Dâhîl), Daru'sSamî', 1. Baskı, Riyad, 1418, s. 171.

71 Şattî, Hasan, Risaletun fi Taklid ve'l Telfik, s. 2.

72 Heyet, Mu'cem'ül- vesît, 382. 
birisinin ölmeyecek kadar içki içmesi veya açlıktan ölmek üzere olan bir şahsın domuz eti yemesi gibi. ${ }^{73}$

Fıkıh literatüründe ruhsat birkaç manada kullanılmaktadır:

- Kolaylık ve kolaylaştırma prensibi anlamıyla ruhsat, başta istislâhî ictihâd olmak üzere fıkhî meseleleri tahlil ederken izlenen bütün ictihâd yöntemlerinde önemli bir etkiye sahiptir. Bu en dar anlamıdır.

- Kişinin farklı mezheplerden kolayına giden en uygun içtihadı alıp amel etmesi manasında kullanılmıştır.

- Hanefi mezhebi literatüründe icma sarih yolla meydana gelmişse azimet, sükûti yolla olmuşsa ruhsat diye nitelendirilir.

- Fıkıh usulünde hadisin gerek zaptı gerekse edası konusunda asıl kabul edilen şekiller azîmet, kolaylaştırma ilkesinden destek alınıp tecviz edilenler ruhsat diye anılır.

- Ruhsat füru fıkıhta ibâha ile aynı anlamda kullanılmaktadır. ${ }^{74}$

Ruhsatı mükellefin filleriyle olan ilişkisini üç kısım olarak açıklayabiliriz:

a) Vacip olan ruhsat; açlıktan ölmek üzere olan bir kişinin ölmeyecek kadar domuz eti veya leş yemesi vacip olan bir ruhsattır.

b) Yapılması daha evla olan ruhsat; yolcu olan bir kimsenin dört rekât olan farz namazları kasr etmesi dört rekât kılmasından daha evladır.

c) Mubah olan ruhsat; bu çeşit ruhsat ise müzdelefe ile arefe dışındaki yerlerde namazları cem etmek mubahtır. ${ }^{75}$

Ruhsatı almanın belli başlı şartları vardır. Bu şartları kısa bir şekilde değinmek faydalı olacaktır:

- Ruhsatı alabilmek için meşakkat ve zorluğun söz konusu olmaz. Tabi ki bu meşakkatte insanların alışıla gediği bir meşakkat olmamalıdır. Soğuk suyla abdest almak gibi. Her ne kadar meşakkatli gözükse de insanlar buna alıştıklarında, burada meşakkat söz konusu olamaz. Mesela soğuk kış günlerinde sıcak su bulamayıp, kişinin teyemmüm yapması meşakkat olarak nitelendirilir.

\footnotetext{
Dönmez, İbrahim Kâfi, “Ruhsat”, DIA, 2008, XXXV, 207.

Dönmez, "Ruhsat", XXXV, 207.

el-Ensârî, Zekeriyyâ b. Muhammed b. Ahmed, Hâşîye 'alâ Şerhi Cem‘i'l-Cevâmi' lil'Mahallî, Beyrut, 1995, I, 121.
} 
- Şeriatın izin verip yasaklamadığı bir şeyde ruhsat vardır. Mesela adam öldürmek, zina etmek, içki içmek veya zülüm etmek için sefere çıkan bir kişi namazı kasr etme ruhsatından faydalanamaz.

- Ruhsatın sebebi ya kati veya zannî olmalıdır. Ruhsatın sebebi şüpheli olması halinde ruhsat söz konusu olamaz. Çünkü hükümler şüpheyle icra edilmez.

- Ruhsatın sebebi daha sonra meydana gelecek veya meydana gelmesi beklenen bir olasılığı olmamalıdır. Bilakis ruhsatı alabilmek için olayın bizzat meydana gelmesi gerekmektedir.

- Ruhsatın şeri bir dayanağı olmalıdır. Muteber bir delile dayanmayan bir ruhsatın bir kıymeti harbiyesi yoktur.

- Ruhsatla amel edecek kişinin, ruhsatın şartlarını ve sınırlarını bilmesi gerekir. Mesela açlıktan ölecek bir kimsenin ölmeyecek kadar murdar hayvan yemesi veya ölmeyecek kadar şarap içmesi gibi. mamalıdır. ${ }^{76}$

- Mezhep imamların ihtilaf ettiği ve uzak te'villi ruhsatları araştırıl-

Ruhsatı tanımını yaptıktan ve biraz açıkladıktan sonra şunu diyebiliriz. Ruhsat ile telfîki aynı anlamda değerlendiren âlimler olduğu gibi, telfîk ile ruhsatı farklı değerlendiren alimler de olmuştur.

Telfîk, genel hatları ile ruhsatlara yönelme ile ayrılmakla beraber, bazı yönleri ile de benzemektedir. Hatta bazı âlimler telfîk ile tetebbu ruhasın aynı şeyler olduğunu söylemişlerdir. ${ }^{77}$

İmam Şâtibî ise, ruhsatlara yönelmenin zararlarından birinin de, mezhepler arası telfîke yönelme intimalinin olduğu ve bununda icmanın delinmesi anlamına geldiğini söylemiştir. ${ }^{78}$

Telfîk ile ruhsatın birbirinden ayrıldığı yönleri şu şekilde sıralayabiliriz:

Telfîkte sadece kolaylık olsun diye ve nefsi arzulardan dolayı muteber sayılan delillere muhalefet edilmez. Fakat kolayı isteme durumunda bu şartlar dikkate alınmaz. Telfîk tek bir mesele bağlamında gerçekleştiğinde farklı meselelerde farklı mezheplerdeki ruhsatlarla amel edilmesi anlamındaki ittibâu'rruhas kavramından ayrıır. Yani telfîk iki veya daha fazla görüşün birleştirilme-

76 Remuylî, Tağayyuri-l Fetva, s. 265-266.

77 Dusurî, Câsım Fuheyd, Zecrü’s-Sufehâ 'an Tetebbu'Ruhesi'l-Fukahâ, Beyrut, 1992, s. 13.

78 Şâtibî, el-Muvâfakât, IV, 513. 
sinden oluşurken ittibâu'r-ruhas durumunda böyle bir şey söz konusu değildir. ${ }^{79}$

\section{Telfîk ile Teysîru’l-Fetvâ Arasındaki İlişki}

Teysîr kelimesi, sözlükte kolaylık manasında olup zorluğun zıt anlamIısıdır. ${ }^{80}$ Bundan dolayı Allah-u Teâla yüsr (kolaylık) ile usr'u (zorluk) karşılaştırmıştır. "Şüphesiz her zorluğun ardından bir kolaylık vardır."81

Fetva kelimesi, ismi mastar olup açıklık manasındadır. Bir işte fetva verdi demek, o işi açıklayıp izhar etti, manasındadır. ${ }^{82}$ Fetva terimine birçok tanım yapılmış olup, biz bu tariflerden en iyisi olan Buhûtî'nin (ö. 1051/1641) tarifini söyleyelim: "Şer'î bir hükmü soran bir kimseye fıkhın hükmünü açıklamaktır."83

Teysîru'l-Fetva ise, müftünün kendisine şer'i bir hükmü soran kimseye, sorduğu konu hakkında müftünün farklı fetva verme alternatifi olması durumunda, soran kişinin durumuna bakarak ona uygun fetva vermesine denir. Tabi ki şer'i bir çıkış yolu varsa, müftü o yolu göstermelidir. Allah-u Teâlâ'nın insanoğluna açtığı çıkış yollarını da kapatmamak gerekir.

Burada ki kolaylıktan maksat zaruri bir durum meydana gelmeden haram bir şeyi mubah saymak, vacibi terk etmek ve ifsadı amaçlamak değildir. Çünkü böyle bir şey hukuka halel getirir.

Müftü bir mesele hakkında şer'i delillere bakıp o mesele hakkında hüküm verdikten sonra, verdiği hükmün zıttı olacak şekilde başka bir hüküm veremez. Mesela eşini üç talakla boşayan bir kimse müftüye gelip hüküm sorduğunda müftü de şer'i delillere bakarak, adama eşinin kendisine haram olduğunu, ancak başka bir kimseyle evlendikten sonra kendisiyle tekrardan evlenebileceğini söylerse, daha sonra eşini boşayan kimsenin ailesine bakıp yuvası dağılmasın diye önce ki verdiği fetvasından dönemez. ${ }^{84}$

Müftü bir konu hakkında delil olmasına rağmen kişiye kolaylık olsun diye fetva verdiğinde bu teysîru'l-fetva bağlamından ele alınmayıp, aksine aşırılık olarak nitelendirilir. Çünkü verilen fetva hukuka muhaliftir. Hukuka muhalif olan bir şey de ise kolaylık söz konusu olamaz. Hatta kolaylık olsun diye

\footnotetext{
79 Ölmez, Mezhepler Arası Telfik, s. 46.

80 Heyet, Mu'cem'ül- vesît, 1123.

81 İnşirah, 94/5.

82 Heyet, Mu'cem'ül- vesît, 721.

83 el-'Atıbî, et-Telfik beyne'l-Mezâhib, s. 36.

84 el-Atıbî, et-Telfik beyne'l-Mezâhib, s. 35- 36.
} 
verilen fetva insanlar için içinden çıkılmaz bir hal alıp, zorlaşır. Mesela hırsızlık suçu işleyen bir kimsenin elinin kesilmesi yerine alternatif olarak hapsedildiği zaman bu insanların mallarının zayi olması demektir. Çünkü bu ceza hırsızlara hafif gelir. ${ }^{85}$ Günümüzde de görmekteyiz ki hırsızlık suçunu yapıp hapse giren kimse uslanmamakta, hatta çıkar çıkmaz tekrar hırsızlık yapmaktadır.

Teysîru'l-Fetva'nın kaideleri ise şöyledir:

- Fetvalarda olan kolaylık şeriatın usulüne uygun olmalıdır. Şeriatın onayladığı bir kolaylık olmalıdır. Şeriata muhalif hiçbir kolaylık makbul olmayıp batıldır.

Şâtibî bu kurala binaen şöyle söylemektedir: "Kolaylık olan Hanif din, ancak kendi usulüne bağlı olduğu takdirde kolaylık vardır. Tetebbu'u-r-ruhas ve kişinin nefsinin hoşuna giden şeriatın usulünden değildir." 86

- Teysiru'l-fetva, şeriatın insanı mükellef tuttuğu şeyleri kaldırmamaIıdır. Teysîru'l-fetva bizatihi amaç olmayıp insanoğlunun Allah'a itaat etmeyi, toplumun düzenini sağlama ve işlerinde kolaylık olması açısından bir vesiledir. Şayet teysîru'l-fetva insanın düzenini bozar ve Allah'tan uzaklaştırıyorsa bu fetva amacının dışına çıktığından kabul edilemez.

- Teysiri gerektirecek şer'i bir zorluk sürekli olmalıdır. Zorluğun olmadığı yerde kolaylıktan bahsedilemez. Kolaylık ve zorluk açısından şeriatın dört hükmü vardır.

1. Başlangıçta teysir ve hafiflik olsun diye meşru olan hükümlerdir. Taharet ve ibadetlerin hüküm ve rükünleri gibi.

2. İlk başta zor olsun diye meşru kılınan hükümlerdir. Zinanın haram olması, faizin haram olması ve ölü etinin haram olması gibi.

3. Kolaylık üzerine olan hükmün, zor olan bir hükümle nesh edilmesi durumu. Ramazan ayında fidye ile oruç arasında bir muhayyerlik söz konusu iken daha sonra gelen ayette bu hükmün yerini sadece oruç alması gibi.

4. Hüküm ilk başta zorluk üzerine bina edildikten sonra, kolay olan bir hükümle nesh edildiği durum. Kocası ölen kadın bir yıl iddet bekliyorken, bunun dört ay on güne indirilerek geçmiş hükmü nesh etmek gibi. ${ }^{87}$

- Fetva veren müftünün verdiği fetvada kolay kaçtığı bilinen biri olmayacak. Böyle birisinin verdiği fetvaya itibar edilmez. ${ }^{88}$

\footnotetext{
85 el-'Atıbî, et-Telfik beyne'l-Mezâhib, s. 36.

86 Şâtibî, el-Muvâfakât, IV, 511.

87 el-Atıbî, et-Telfik beyne'l-Mezâhib, s. 37-38.
}

ÇÜiFD, 2018, cilt: 18, sayı: 1, ss. 535-567 
Telfîk ile Teysîru'l-Fetva arasında bir bağ vardır. Zira Teysîru'l-fetva tanımı ve şartlarına baktığımızda telfikle uyuştuğunu görürüz. Teysîru'lfetva'ya zaruret ve intiyaç anında başvurulmaktadır. Aynı durum telfîkte de söz konusudur. Ulemanın çoğu da bu görüşte olup, telfikin zaruret ve ihtiyaç olması durumunda caiz olduğu kanaatindedirler. ${ }^{89}$

\section{TELFÎK ILEE INTIKKAL ARASINDAKI ILIŞKi}

İntikal ve telfîk kavramları farklı mezheplere ait görüşler ile amel edilmesi meselesi üzerinde ortaya çıkmaları cihetinden birbirlerine benzerlik arz ederler. Biraz sonra değineceğimiz üzere intikale cevaz vermekle birlikte birtakım şartlarla bunu sınırlandırmaya çalışan İslam hukukçularının, intikal ile telfîki birbirinden ayırmaya çalıştıkları söylenebilir. Bahsedilen sınırlandırmalar yapılmazsa intikal, telfîke götüren bir vasıta haline gelebilir. Bundan dolayı intikali savunan âlimler telfîke karşı çıktıklarını göstermek amacıyla bu şartlar üzerinde hassasiyetle durmaktadır. Bir mukallit iki görüşle, bir arada veya aynı zaman içerisinde amel etmiyor, ikinci görüş ile amel ederken birinci görüşteki hüküm ile ilgili bir netice doğmuyor ise burada telfîkten söz edilemez. Abdestli bir kimsenin kan aldırmakla abdestinin bozulmayacağı hususunda Şafii'nin, kadınlara dokunmanın abdeste herhangi bir halel getirmeyeceği hususunda ise Ebû Hanife'nin görüşüyle amel ederek namaz kılması örneğinde telfîkin ortaya çıkardığı hüküm batıl sayılır. Başının bir kısmını mesh etme konusunda Şâfiî̀yi taklîd edip, köpeğin necis olmadığı hususunda ise Mâlik'in görüşüyle amel ederek namaz kılmak telfîke verilen meşhur örneklerden bir diğeridir. ${ }^{90}$

Telfîkin gerçekleşebilmesi için mukallidin iki farklı mezhebin görüşüyle aynı anda amel etmesi gerekir. Örneğin mukallidin görüşlerden birine bir zamanda, diğerine başka bir zamanda uyması telfîk olarak adlandırılmamaktadır. Telfîk ile kastedilen, bir meselede başka bir ifadeyle özel bir konuda birbirine zıt olan iki yahut daha fazla mezhep görüşlerinin yukarıdaki örneklerde görüldüğü üzere bir araya getirilerek cem edilmesidir. Seyyid Bey, "fıkhî meselelerde mezheplerden birinin görüşüyle amel edilmesine telfîk denilmediği gibi hazırlanan bir kanun layihasının farklı maddelerinde farklı mezheplerin hükümlerinden yararlanılmasına da telfîk denilmez" diyerek bunun telfîk zannedildiğine dikkat çekmiştir. ${ }^{91}$

\footnotetext{
88 el-'Atıbî, et-Telfik beyne'l-Mezâhib, s. 38.

89 el-'Atıbî, et-Telfik beyne'l-Mezâhib, s. 39.

90 İzmirli, İlmu'l-Hilâf, s. 271.

91 Seyyid Bey, Medhal, Matbaa-i Âmire, İstanbul, 1914, s. 315.
} 
İzmirli İsmail Hakkı, telfîkin iki türünden bahseder. Birincisi bir meselede meydana gelen telfiktir. Kan akması konusunda Şafii'nin, kadına dokunma konusunda ise Ebû Hanife'nin taklîd edilmesi örneğinde olduğu üzere bir meselede farklı görüşlerle amel edilmesi telfîkin birinci türünü oluşturur. İkincisi ise iki farklı meselede meydana gelen telfiktir. İmirli İsmail Hakkı farklı meselelerde mezheplerin birbirine muhalif görüşlerini taklîd etmeyi telfîk başlı̆ı altında işler. O Hanefi mezhebinin Ebû Hanife ve İmameyn'in görüşlerinin telfîkinden oluştuğu düşüncesini ileri sürerken yahut da menfaatin tazmini konusuna yönelik bazı meselelerde müteahhir Hanefi fakihlerinin Şâfî mezhebinin görüşüyle amel ettiklerini belirtirken telfîki, sözü edilen bu ikinci anlamda kullanmaktadır. Farklı meselelerdeki görüşlerin bir araya getirilmesi yukarıda dikkat çekildiği üzere telfîk kapsamında değerlendirilmemektedir. Fıkıh usulü eserlerinde bu konu mezhepler arasında intikal kavramı altında ele alınmıştır. ${ }^{92}$

Mukallidin kendisine kolay gelen ve daha az sorumluluk gerektiren mezheplerin hükümleri ile amel etmesi konusu fıkıh usulü eserlerinde ittibâu'rruhas kavramıyla ifade edilmektedir. Bu kavram mükellefin her bir konuda mevcut içtihatlardan daha kolay ve hafif olanları tespit ederek onların gereği ile amelini ifade eder. Telfik, ittibâu'r-ruhas ve intikal kavramları mukallidin farklı mezheplerin hükümleri ile ele almaları cihetinden birbirlerine benzerlik arz eder. Itttibâu'r-ruhas, faklı meselelerde farklı mezheplerin görüşlerine başvurulması düşüncesini merkeze alması bakımından telfîkten ayrılır. Zira telfîk yapılırken ittibâu'r-ruhas faaliyetinin aksine bir meselede farklı mezheplerin görüşleri birleştirilerek, o mezheplerden birinin savunmadığı üçüncü bir görüş elde edilmektedir.

Mezheplerin farklı meselelerdeki görüşlerinin alınması cihetinden intikal kavramı, ittibâu'r-ruhas kavramına benzemektedir. Intikal ve ittibâu'rruhas'ı savunan âlimler, mukallidin tüm meselelerde mensubu olduğu mezhebin görüşleri ile amel etmesi gerektiğini düşünmemektedir. Intikal yoluyla mezheplerin ruhsat hükümleri ile amel edilmesinin mümkün olması intikal ve ittibâu'r-ruhas kavramları arasındaki başlıca ortak noktadır. Bu iki kavramı ayırmak üzere intikali savunan âlimler, intikale cevaz verilebilmesi için mukallidin ruhsat hükümleri ile amel etme gayesi taşımasını koştukları temel şartlardan biri olarak ileri sürmüşlerdir. Mukallidin kendisine daha kolay gelen hükümler ile amel etmesine giden yolların kapatılmak istenmesi, intikale cevaz veren âlimlerden bir kısmının ittibâu'r-ruhasa karşı çıktığına işaret etmektedir.

92 İzmirli, İlmu'l-Hilâf, s. 271-275.

ÇÜiFD, 2018, cilt: 18, sayı: 1, ss. 535-567 
Zira amminin (fıkhı bilmeyenin) kendisine kolay gelen ve maslahatına uygun olan görüşü seçmesi ittibâu'r-ruhasın zorunlu bir unsuru iken, intikal kavramı bağlamında böyle bir zaruretin öne çıkartılmasından hassasiyetle kaçınılmaktadır. Ruhsat hükümleri ile amel edilebileceğini savunan isimlerin tamamının ise intikali mümkün gördükleri söylenebilir. İntikal, telfîk ve ittibâu'r-ruhas kavramlarının ortak özelliği ise intisap alanının belli bir mezheple sınırlı olmadığı düşüncesini temel almasıdır. ${ }^{93}$

İntikal kavramı İslam hukuku uleması tarafından kullanılmış bir kavramdır. Intikal kavramı fıkıh ve usul eserlerinde mukallid olan bir kimsenin taklit ettiği mezhebin bütün görüşlerini mi yoksa belli başlı meselelerde taklit edilmesi gerektiği hususunda meydana gelen tartışmalar intikal kavramının alt yapısını hazırlamıştır. ${ }^{94}$ İntikal kavramının furu'i fıkhın farklı alanlarında borcun, alacağın, bir arazi üzerindeki tasarruf yetkisinin yahut da terekenin (miras) sahibinden bir başkasına geçmesini ifade etmek üzere kullanıldığı görülmektedir. ${ }^{95}$

İntikal kavramın tarihi serüveninde tespit edilebildiği kadarıyla en önemli gelişme, intikal kavramının temelinde yatan düşüncenin taklîdin tecezzisi kavramıyla karşılanmaya çalışılmasıdır. İntikali savunmasıyla öne çıkan Şah Veliyullah 'ın, Dihlevilik kavramı ile ifade edilen ilmi çevresinin merkez simalarından biri olan İsmail b. Abdülgani eş-Şehid (ö.1831) bahsedilen kavramı kullanmıştır. Bu kavramın içtihadın parçalanabileceği düşüncesinden hareketle üretildiği anlaşılmaktadır. İsmail eş-Şehid belli bir mezhebi taklîd eden mukallidin, bir meselede başka bir müçtehidin görüşüyle amel edebileceği düşüncesini, ictihâdın tecezzisi gibi taklîdin de tecezzi edebileceğini söyleyerek temellendirmiştir. Onun taklidi tecezzi edebileceği düşüncesi Şah Veliyullah'ın mezhepler arası intikal anlayışıyla benzerlik arz eder. ${ }^{96}$

93 Aydın Ahmet, "Taklid Kavramına dair Tartışmalardan Biri Olarak Mezhepler Arası İntikal Meselesi", ŞÜIFD, 2013/1, IV, sayı:7, s. 16.

94 Kaya, Eyyüp Said, Mezheplerin Teşekkülünden Sonra Fıkhi İstidlal, (basılmamış doktora tezi), MUSBE, 2001, s. 64.

95 Akgündüz, Ahmet, "İntikal”, DiA, XXII, 353-356.

96 Aydın Ahmet, "Taklid Kavramına dair Tartışmalardan Biri Olarak Mezhepler Arası İntikal Meselesi”, s. 16. 


\section{1. İntikalin Hükmü}

İntikalin söz konusu olabilmesi için belli bir mezhebe intisap etmiş mukallid bir kimsenin başka bir mezhebe geçmesi durumudur. Hiçbir mezhebe intisabı olmayan bir kimsenin tutup ta mezhepler arası intikal etmesine âlimlerin çoğunluğu tarafından uygun görülmeyip ve tasvip edilmemiştir. ${ }^{97}$

İzmirli İsmail Hakkı Âmidî (ö. 631/1233), İbnü'l-Hâcib (ö. 649/1249), İbn Bürhân (ö.676/1277), Nevevî (ö.676/1277) ve İbnü’l-Hümâm'ın bu görüşü savunan âlimler arasında öncü şahsiyetler olduğunu belirtmektedir. ${ }^{98}$

Belli bir mezhebe intisap eden bir kimsenin, başka bir mezhebe intikal etmesi durumu üzerinde iki temel görüş vardır:

a. Bir mezhebe bağlı olduğunu söyleyen bir kimsenin o mezhebin görüşüne aykırı bir mezhebin görüşünü alamaz. Mezhebinde bulunan görüşe göre de amel etmesi gerekir.

b. Bir mezhebe iltizam etmek başka bir mezhebin görüşünü almak manasına gelmemektedir. Dolayısıyla bir mezhebe bağlı bir kimsenin başka bir mezhebin görüşüne göre amel etmesinde bir mahsur yoktur.

Söz konusu ihtilaf mukallitlerin her biri cüz'i meselede mi müçtehitleri taklîd ettikleri yoksa bir mezhebi icmali olarak mı taklîd ettikleri konusunda taklîd kavramının çerçevesinin çizilmesine yönelik yaklaşım farklılıklarından kaynaklanmaktadır. İslam hukukunda mezhepler oluşmadan önce insanlar herhangi bir mezhebe bağlı değillerdi. İnsanlar, şer'î bir hükmü birden fazla kişiye sorabiliyor ve bunun sonucunda birisiyle amel ediyorlardı. Hatta bu durum sahabe ve tabiun zamanında da vardı. Hiçbir kimse insanların bu tutumunu eleştirip reddetmiyordu. ${ }^{99}$

\subsection{Mezhepler Arası İntikalin Şartları}

İntikalin sahih olabilmesi için aranan şartlara bakıldığında bu konudaki ulemanın yaklaşımlarını mukallidin bir mezhebin görüşüyle amelinin bir kıstas olarak dikkate alınması temelinden ikiye ayırmak mümkündür. Mukallidin amelini dikkate almayan İslam hukuku âlimleri bir takım farklı şartlar ileri sürerek intikalin alanını sınırlandırmaya çalışmaktadır. İntikalin caiz olduğunu savunan fıkıh âlimlerinin büyük çoğunluğu intikal yapabilmek için mukallidin bir

97 Aydın,“Taklid Kavramına dair Tartışmalardan Biri Olarak Mezhepler Arası İntikal Meselesi”, s. 24.

98 İzmirli, İlmu’l-Hilâf, s. 271.

99 Aydın, "Taklid Kavramına dair Tartışmalardan Biri Olarak Mezhepler Arası İntikal Meselesi", s. 17. 
meselede mezhebinin görüşü ile amel etmemesini temel bir şart olarak ileri sürmüşlerdir. Fıkıh âlimleri arasındaki bu ortak görüşe değinen Erdebilî (ö. 779/1377), mezhepte intikalinin mümkün olabilmesi için Usul Fıkıh ulemasının tek şart ileri sürdüklerini dile getirmektedir. Bu şart da mukallidin intikal etmek istediği meselede mezhebinin görüşü ile amel etmemiş olmasıdır. ${ }^{100}$ İmam Zerkeşî (ö. 794/1392) isimlerini zikretmediği bazı usul âlimlerinin amel ettikten sonra mukallidin taklîd ettiği görüşü terk edemeyeceği hususunda icma olduğunu söylediklerini nakletmektedir. ${ }^{101}$

İntikâl konusunda, ameli bir ölçü olarak dikkate almayan fıkı âlimleri, hükmün nakzedilmesi gereken konuları dışarıda bırakarak intikalin sahasını genişletmekte yahut da bir takım farklı şartlar ileri sürerek bu sahayı daraltmaya çalışmaktadırlar. Fıkıh âlimlerinin bu konuda ileri sürdükleri şartlarda mukallidin sadece mezheplerin kendine kolay gelen hükümlerini tercih etme gayesiyle buna başvurmasının önüne geçilmesine yönelik yoğun bir çaba kendisini hissettirmektedir. Bu konuyu tartışan Maliki fakihi Muhammed b. İshak b. Ayyâş ez-Zenatî (ö.618/1221) intikalin geçerli sayılabilmesi için üç temel şart ileri sürmüştür.

1. Mezheplerin farklı hükümleri icmâya muhalif olacak biçimde bir araya getirilmemelidir. Mehirsiz, şahitsiz ve velinin izni alınmaksızın kıyılacak bir nikâhı geçerli saymak, sözü edilen bu duruma bir örnek gösterilebilir. Ulaşılan bu hüküm, hiçbir mezhep tarafından müstakil bir şekilde savunulmamaktadır. Zinaya yol açması sebebiyle bu hükme karşı çıkıldığı ifade edilmektedir. ${ }^{102}$

2. Bir kimsenin taklîd ettiği müçtehidin üstün olduğuna inanmasıdır. Nitekim körü körüne ve bağlı olduğu mezhebi bilmeden taklîd etmek caiz değildir.

3. Mezhepler arası yapılacak olan intikalin mezheplerin ruhsat hükümlerinden yararlanma gayesi ile yapılmamasıdır. Çünkü mezhepler, kişiyi cennete, hayra ve kişiyi mutluluğa eriştiren yollardan biridir. Kim bu yollardan birine girerse amacına ve gayesine ulaşacaktır. ${ }^{103}$

100 el-Erdebîlî, Cemâlüddîn (İzzuddîn) Yusuf b. İbrahim, el-Envâr li’A ‘mâli’ I-Ebrâr, ts. III, 462.

101 ez-Zerkeşî, Ebû Abdullah Bedruddin Muhammed b. Bahadır b. Abdullah, el-Bahru'l-Muhît fî Usûli'l-Fıkh, VI, 320-321.

102 Karâfî, Şerhu Tenkîhi'l-Fusûl, s. 339.

103 Karâfî, Şerhu Tenkîhi'l-Fusûl, s. 339. 
Hanefi mezhebinin ulemasından İbn Emir el-Hâc'ın (ö.879/1474) bu şartları Zenatî'ye göre daha erken bir dönemde yaşamış olan Şâfiî Kadısı Ebu'l-Mehâsin Abdulvahid b. İsmail er-Rûyânî'ye (ö. 502/1108) yanlışlıkla izafe ettiği görülmektedir. Zenatî'nin intikâl konusundaki yaklaşımı ibn Cüzey (ö. 741/1340) gibi Mâlikî uleması tarafından kabul görmektedir. Hanbelî mezhebi fıkıh âlimi Saffarinî de yukarıda zikredilen üç şartı kabul etmekte ve isimlerini vermeden bu şartları muhakkik fıkıh âlimlerine izafe etmektedir. ${ }^{104}$

İbn Emir el-Hâc İbn Dakik el-'Îyd'in (ö.702/1302) Rûyânî'nin intikâl için ileri sürdüğü şartlardan birincisini kabul ettiğini söyler. İbn Dakik el-'İyd, erRûyânî'ye kabul ettiği ikinci şartı kabul etmeyip değiştirmiştir. Kendisi intikâlin caiz olması için üç temel şart bulunduğunu kabul etmektedir. Buna göre birincisi, taklîd edilecek hüküm mezheplerin farklı görüşlerinden icmâya muhalefet edecek biçimde bir araya getirilmemelidir. İkincisi, taklîd edilmemiş hüküm nakzedilmiş olmamalıdır. Üçüncüsü, intikâl dini hafife alan kolaycı bir tavırla gerçekleştirilmemelidir. ${ }^{105}$

Zenâti'nin şartlarından ilk ikisini benimseyip kabul eden Abdullah b. İbrahim eş-Şenkitî (ö. 1233/1819) ise son şartı değiştirerek bunun yerine İzzeddin b. Abdusselâm (ö. 660/1262) gibi, hâkimin hükmünün zıt olmadığı konularda intikal yapılabileceği şartını ileri sürmektedir. ${ }^{106}$

Her mezhebin nefse hoş gelen hafif hükümlerini araştırıp onları benimsemek konusuna gelince; bu meselede dikkate alınması gereken iki durum vardır: Biri her mezhebin hafif hükümlerini araştırıp seçmek, diğeri fıkhi mezhepleri oyuncak haline getirme maksadıyla saygısızlıktır. Bunlar başka şeylerdir, bunları karıştırmayıp aralarını ayırmamak gerekir. Çünkü ikincisi birincisinin ayrılmayan bir parçası değildir. Yani ikincisinin caiz olmaması birincisinin de caiz olmayacağını gerektirmez. Şu durumda fıkhî mezhepleri kasıtlı olarak oyuncak haline getirmek kötü olduğu için caiz olmamakla birlikte, bu maksatla değil de her mezhebin hafif hükümlerini araştırıp seçmek caiz olabilir. ${ }^{107}$ Çünkü mezhepleri hafife almaksızın sadece kolaylık amacıyla her ekolün kolay hükümlerini alıp seçmek yasak değildir ama kolaycılıktır. Zira peygamberimiz karşılaştığı iki durumdan birini seçmek zorunda kaldığı zaman onların en kolayını seçerdi ve ümmeti hakkında en kolay ve hafif olanı tercih

\footnotetext{
104 İbn Cüzey, İmam Ebu'l-Kasım Muhammed b. Ahmed el-Kelbi, Tekribu'l-Vusul ile IIImi'l-Usûl, yay.y., y.y., ts., s. 112; Aydın, "Taklid Kavramına dair Tartışmalardan Biri Olarak Mezhepler Arası İntikal Meselesi”, s. 27.

105 Zerkeşî, el-Bahru'l-Muhît fî Usûli'l-Fıkh, VI, 322.

106 Şenkitî, Neşrü'l-Bunûd, II, 349-350.

107 Seyyid Bey, Medhal, 307.
} 
ederdi. Ashab-ı kiram'ı, görevlendirdiği vali ve kadılara halka kolaylık göstermelerini, nefret ettirecek taassuptan sakınmalarını öğütlerdi. Bundan ve "Allah sizin için kolaylığı ister zorluğu istemez"108 ve "Allah sizin için hafif olanı ister"109 ayetleri ile "Dininizin en hayırlısı kolay olanıdır"10 ve "Ben kolaylık üzere olan Hanif dini ile gönderildim"111 hadisleri gibi bu hususta gelmiş olan birçok şer'i nasların işaretlerinden anlaşılmaktadır ki, şer'i hükümlerin hafife alma ve hakir görme amacı olmaksızın her mezhebin kolay hükümlerini almak caizdir.

İbnü'l-Hümâm, bazı İslam hukukçuların: "Bir mezhepten diğer mezhebe geçen kişi günahkârdır," ifadelerine cevaben; bir mukallidin gelecekte vuku bulacak durumlar hakkında: "Ben bütün meselelerde Ebû Hanife'yi taklîd ve onun sözleriyle amel etmeyi gerekli gördüm” demesi taklîd olmayıp aksine taklidi gerektiren bir vaatten ibaret olduğunu ifade ettikten sonra sözünü şöyle sürdürür: "Bir mezhepten diğer mezhebe intikal eden kişi günahkârdır, bunu yapması için bir özrü olması gerekir gibi sözler mezheplerin kolay hükümlerini halkın araştırmasını yasaklamak içindir."112

\section{Sonuç}

Müslümanın hayat ölçülerini belirten İslam hukuku, şer'î-amelî olan hükümlerle ilgili bütün konuları içine almaktadır. Biz de şer'î-amelî hükümlerden olan ve günümüzde sıkça rastlanan ve problem haline gelen telfîk konusu ve telfîk ile ilgili olan taklid, mezhepler arası intikal, tetebu'r-ruhas, teysir ve indasu Kavli's-salis gibi kavramlarını da açıklamaya çalıştık. Telfîk konusu; taklid, mezhepler arası intikal, tetebu'r-ruhas, teysir ve indasu Kavli's-sâlis konularıyla her ne kadar bazı noktalarda benzerliği varsa da aslında her biri amelî cihette farklı konular olduğu gözlemlenmiştir.

Telfîkin uygulanabilirliği ile ilgili olarak bu çalışmamızda şu sonuçlara varılmıştır:

Telfîk meselesi ıstılahı olarak hicri yedinci yüzyılda, müçtehidler döneminden sonra ki mukallid döneminde ortaya çıkmıştır. Çünkü müçtehidler döneminde uygulamada telfîk var olmasıyla beraber herhangi bir terimle anı-

08 Bakara, 2/85.

109 Nisa, 4/27.

110 İbni Hanbel, Ebû Abdullah Ahmed b. Muhammed, eş-Şeybânî el-Mervezî, Müsned, IV, 338.

111 el-Münâvî, Zeyneddîn Muhammed Abdürraûf b. Tâcül 'ârifîn b. Nureddin Ali el-Haddâdî, Feyzu'IKadir Şerhu'l-Câmi 'i's-Sağîr, Beyrut, 2002, III, 203.

112 İbnü'l-Hümâm, Şerhu Fethi'l-Kadîr, V, 457. 
mıyordu. Istılah olarak müteahhir fukahâ döneminde kullanılmış ve geliştirilmiştir.

İslam hukukçularının telfîk'in hükmü konusunda üç temel görüşe ayrılmışlardır: birinci görüş mutlak manada telfîki caiz görenler; bu yaklaşıma göre telfîkin yasak olması durumunda insanların zor duruma düşeceğini ve telfîki yasaklayan herhangi bir ayet ve hadis olmadığından dolayı telfîkin mutlak manada caiz olduğu görüşünü benimsemişlerdir.

İkinci görüş telfîki mutlak anlamda caiz görmeyenler; bu akıma göre hak bir olduğu için kişi bir mezhebe ittiba ettiği zaman onun nazarında sahih olan mezhep, bağlı olduğu mezhep kanısında olması gerekir. Bir de telfîki caiz olduğuna dair herhangi bir delilin olmadığını ve dolayısıyla telfîkin caiz olmadığı kanısına varmışlardır.

Üçüncü görüş ise; bazı şartları (amaç kolaya kaçmak olmamalı, yapılan telfîk icmâya muhalif olmamalı ve telfîkin zaruret halinde olması gerekir) öne sürerek ve bu şartların gerçekleşmesi dâhilinde telfîkin caiz olacağını, aksi takdirde telfîkin caiz olmayacağı görüşünü benimsemişlerdir.

Aslında iyi niyetle yapılan, nasların lâfız ve ruhuna aykırı olmayan telfîkin caiz olabileceğini öne süren bilginlerin görüşlerinin daha isabetli olabileceği kanaatindeyiz. Dolayısıyla zaruret ve meşakkat durumlarda oluşan telfîkin caiz, kolaya kaçma, islam fıkhını hafife alma ve şahsî çıkar amacı güdülerek yapılan telfîkin caiz olmadığını ifade edebiliriz. 


\section{Kaynakça}

Akgündüz, Ahmet, “İntikal”, DIA, XXII, 353-356.

el-Âmidî, Ebû Hasan Seyfüddîn Ali b. Ebî Ali, el-Ihkâm fî Usûli'l-Ahkâm, Beyrut, ts.

el-'Atibî, Gazi b. Mürşid Halef, et-Telfîk beyn'l-Mezâhib ve 'Alâkatuhu bi Teysîr el-Fetvâ, Riyad, 2007.

Aydın, Ahmet, "Taklid Kavramına dair Tartışmalardan Biri Olarak Mezhepler Arası İntikal Meselesi”, ŞÜIFD, 2013/1 yıl, IV, sayı: 7.

Dönmez, İbrahim Kâfi, İçtihadın Bağlayıcılığı Meselesi ve Fıkıh Mezheplerine Bağlanmanın Anlamı, Usul İslam Araştırmalar, 2004. "Ruhsat", DIA, 2008, XXXV, 207.

Dusurî, Câsım Fuheyd, Zecrü's-Sufehâ ‘an Tetebbu'Ruhesi'l-Fukahâ, Beyrut, 1992.

Düsûkî, Şemseddin Şeyh Muhammed Urfa, Haşiyetü'd-Desûkî ala Şerhi'lKebir, Daru İhyai'l-Kütübi'l-Arabiyye, Kahire, ts.

ed-Dimyâtî, Ebî Bekr Osman b. Muhammed Şettâ el-Bekrî, lânetu-Talibîn, Daru'l Kutubi'l İlmiyye, I. Baskı, Beyrut, 1415.

el-İsnevî, Abdürrahim b. Hasan eş Şâfiî, Süllemü'l-Vusûl Şerhu Nihâyetu'sSu'l, Daru'l Kutubi'l İlmiyye, Beyrut, 2009.

el-Ensârî, Zekeriyyâ b. Muhammed b. Ahmed, Hâşîye 'alâ Şerhi Cem'i'lCevâmi' lil'Mahallî, Beyrut, 1995.

el-Erdebîlî, Cemâlüddîn (İzzuddîn) Yusuf b. İbrahim, el-Envâr li’A ‘mâli' l-Ebrâr, ts.

Gazzâlî, Ebû Hamid Muhammed b. Muhammed, el-Mustasfâ min İlmi'l-Usûl, el-Mektebetü'l-Asriyye, Beyrut, 2009.

Halid Hasan, el-Kavlu's-Sedîd fî Ba'zi Mesâil'il-ĺctihâd ve't-Taklîd, yy. , Suudi Arabistan, 2006.

el-Haskefî, Muhammed b. Ali, ed-Dürrü'l-Muhtâr Şerh Tenvîri'l-Ebsâr, Daru'l Kutubi'l İlmiyye, Beyrut, 2002.

el-Helvanî, Şihâbuddîn Ahmed b. İsmail, el-Vesm fil-Veşm, (Thk: Ahmed Berrak), Matbuatu Nercis, Riyad, 1426.

Heyet, el-Mu'cem'ül- Vasît, Mektebetü'ş-Şûruki'd-Düveliyye, 2004.

el-Heytemî, Şihâbuddîn b. Ahmed b. Muhammed b. Ali İbn Hacer el Fetâva'lFıkhiyye el- Kübrâ, Daru's-Sadr, Beyrut,1997. 
el- Hindî, Muhibullah b. Abduşekûr Musellu-Subût, Matbuatu Bûlâk, I. Baskı, 1322.

el-Hüseynî, M.Reşid Rıza, İslam'da Birlik ve Fıkıh Mezhepleri, (trc.: Hayrettin Karaman), Ankara, 1974.

İbn Abidîn, Seyyid Muhammed Emin b. Ömer b. Abdülaziz, Haşiyet'ül-Reddü'l Muhtar âle'd-Düreri'l- Muhtar, Matbuatu Mustafa Elbanî el- Halebî, II. Baskı, Mısır, 1386.

İbn Cüzey, İmam Ebu'l-Kasım Muhammed b. Ahmed el-Kelbi, Tekribu'l-Vusul ile İlmi'l-Usûl, yay.y.,y.y., ts.

İbn Hanbel, Ebû Abdullah Ahmed b. Muhammed, eş-Şeybânî el-Mervezî, Müsned, Mısır, ts.

İbn Hazm, Ebû Muhammed Ali b. Ahmed b. Said b. Hazm, el-Endelüsî elKurtubî ez-Zâhirî, el-Ihkâm fi Usûli'l-ehkâm, Mektebetü'l Asriyye, Beyrut, 1405.

İbn Manzûr, Ebu'l-Fadl Cemâlüddîn Muhammed b. Mükrem, Lisânu'l-'Arab, Daru Sâdır, III. Baskı, Beyrut, h.1414.

İbnü'l-Hümâm, Kemâlüddîn Muhammed b. Abdilvâhid b. Abdilhamîd esSivâsî, Şerhu Fethi'l-Kadîr, Dâru'l-Kutubi'l-IImiyye, Beyrut, h. 1316. , et-Tahrir fi Usûli'l Fıkh, Daru'l Kutubi'l İlmiyye, Beyrut.

İzmirli, İsmail Hakkı, İlmu'l-Hilâf, Darı Saadet, İstanbul, 1912.

el- Karâfî, Ebu'l Abbas Şihâbuddîn Ahmed b. İdris b. Abdurrahman el- Malikî, Şerhu Tankîhu'l-Fusûl, (Thk: Taha Abdürraûf), Daru'l Fikr, I. Baskı, Kahire, 1393.

Karaman, Hayreddin v.diğ., IIImihal İman ve Ibadetler, Ankara, 2006. , İslam Hukukunda İçtihat, Ensar Neşriyat, İstanbul, 2010. İçtihat Taklid ve Telfik Üzerine Dört Risâle, İstanbul, 2002.

Kaya, Eyyüp Said, "Telfîk”, DIA, 2011, XL, 401-402.

, "Taklid", DIA, İstanbul, 2010, XXXIX, 461-465.

Mezheplerin Teşekkülünden Sonra Fıkhi İstidlal, (basılmamış doktora tezi), MÜSBE, 2001.

el-Kurtubî, Ebû Muhammed Alî b. Ahmed b. Saîd b. Hazm el-Endelüsî, el Muhallâ bil Asâr, Dâru'l-Kutubi'l-İlmiyye, Beyrut, 2010.

el-Merdâvî, Alâuddîn Ebu'l Hasan Ali b. Süleyman, El-Insaf Fi Marifeti erRacih mine'l Hilaf, (Thk: Abdullah Türkî), Daru'l Hicret, 1416.

el- Murûvî, Muhammed b. Abdülazim, Kavli Sedîd fî Ba'zi Mesâil'il-Ictihâd ve’t-

Taklîd, (Thk: Câsım Yasin), Daru-Da'vet, Kuveyt, I. Baskı, 1408. 
Muhammed Emin Padişah, Teysîr-Tehrîr, Daru'l Kutubi'l İlmiyye, Beyrut.

el-Münâvî, Zeyneddîn Muhammed Abdürraûf b. Tâcül 'ârifîn b. Nureddin Ali el-Haddâdî, Feyzu'IKadir Şerhu'l-Câmi 'i's-Sağîr, Beyrut, 2002.

Ölmez, Sadi, Mezhepler Arası Telfik ve Ulemanın Telfik Ille IIlgili Görüşleri, (Yayımlanmamış Yüksek lisans Tezi), YYU, 2016.

Pezdevî, Ebü'l-Hasen Ali b. Muhammed, Kenzü'l-Vüsûl ilâ Ma'rifeti'l-Usûl, Dâru'l-Kutubi'l-'İmiyye, Beyrut, ts.

er-Râzî, Muhammed b. Ebû Bekir b. Abdulkadir, Muhtâru's-Sihâh, Mektebu Lubnan, Beyrut, 2006.

Remuylî, Abdülkerim, Tağayyuri-l Fetvâ bi Tağayyuri'-। İçtihâd, Daru'l-Kutubi'l İlmiyye, 1971.

Sefârinî, Muhammed b. Ahmed, Risaletu Sefârînî fil Telfik, (Thk: Abdülaziz Dâhîl), Daru's-Samî', I. Baskı, Riyad, 1418.

es-Sa'îdî, Abdullah b. Muhammed b. Hasan, et- Telfîk ve Hukmuhu fi'l Fıkhi'l İslamî, yy.

Senhurî, Abdurrezzâk Ahmed, et-Telfîk beyne Ahkâmi'l-Mezâhib, elMü'temeru'l-Evvel li-Mecme'i'l-Buhûsi'l-İslamiyye.

Serahsî, Ebû Bekir Muhammed b. Ahmed, Usûlü’s-Serahsî, Beyrut, 2005.

Seyyid Bey, Medhal, Matbaa-i Âmire, İstanbul, 1914.

Şâtıbî, İbrahim b. Musa b. Muhammed el-Lahmî, el-Muvâfakât, Daru İbn Affân, 1997.

Şîrâzî, Ebû İshâk İbrâhim b. Ali b. Yusûf, el Mühezzeb, Dâru'l-Fikr, Beyrut, 2004.

Zuhaylî, Vehbe, “Mezhep Hükümlerinin En Kolayını Almada Kurallar”, (çev. M. Nurullah Aktaş), İslâm Hukuku Araştırmaları Dergisi, 2006, sayı: 7, s. 397-432. el-Fıkhu'I-Islâm ve Edilletuhu, Daru'Fikr, Dımaşk, 1986. 


\section{The Theory of Telfiq in Islamic Jurisprudence}

Citation / @- Demirtaş, E. - Sizgen, İ. (2018). The Theory of Telfiq in Islamic Jurisprudence, Çukurova University Journal of Faculty of Divinity, 18 (1), 535-567.

Abstract- Islamic Law is a vibrant, dynamic and effective law. Islamic law has taken this dynamism from the case-law of scholars. As a matter of fact, "The change of the provisions can not be denied by the change of the time", which takes place in the law of the Mejelle and which the scholars give importance, expresses this clearly. From the juristical- applied provisions and the telfiq which has become a problem in our age and it is understood that although the texts such as imitation, intersectarian transfer, tetebbu'r-ruhas, teysir, and ihdasu Kavli'ssalis (the third view revealing) are basically the same as each other, it is understood that these concepts are opposite to each other in the applied dimension. The telfiq, which means to unite different opinions and judgments, has been a subject that has been debated among proceduralists since the seventh century. The telfiq, which is an issue based on iitihad in Islamic Law, is usually mentioned in the imitation of the books of the methods. Therefore, the telfik is divided into two parts, ijtihad and taqlid. Ismail Hakkı Izmirli dealt with the telfiq in two parts, in one case and in two cases. Sayyid Bey divided the telfiq into two; suitable for ijma and not suitable. After the period of the mujtahids, telfiq was referred in practice and it was also accepted by Islamic scholars as long as this practice did not undervalue religion's provisions. There are also scholars who claim that the application of the telfiq is not permissible. However, their attitude has been criticized with expressions such as extremism and bigotry, and the telfiq was accepted by scholars, provided that it is not contrary to the spirit of the main texts.

Keywords- Telfiq, taqlid, ijtihad, Islamic law, teysir 